BANCA D'ITALIA

E U RO S I S T E M A

Temi di discussione

(Working Papers)

Energy costs and competitiveness in Europe

by Ivan Faiella and Alessandro Mistretta 

$\mathbb{B}^{3}$ BANCA D'ITALIA

E U R O S I S T E M A

\section{Temi di discussione}

(Working Papers)

Energy costs and competitiveness in Europe

by Ivan Faiella and Alessandro Mistretta

Number 1259 - February 2020 
The papers published in the Temi di discussione series describe preliminary results and are made available to the public to encourage discussion and elicit comments.

The views expressed in the articles are those of the authors and do not involve the responsibility of the Bank.

Editorial Board: Federico Cingano, Marianna Riggi, Monica Andini, Audinga Baltrunaite, Marco Bottone, Nicola Curci, Davide Delle Monache, Sara Formai, Francesco Franceschi, Salvatore lo Bello, Juho Taneli Makinen, Luca Metelli, Mario Pietrunti, Massimiliano Stacchini.

Editorial Assistants: Alessandra Giammarco, Roberto Marano.

ISSN 1594-7939 (print)

ISSN 2281-3950 (online)

Printed by the Printing and Publishing Division of the Bank of Italy 


\title{
ENERGY COSTS AND COMPETITIVENESS IN EUROPE
}

\author{
by Ivan Faiella* and Alessandro Mistretta*
}

\begin{abstract}
The worldwide upswing in energy prices recorded in the last decade has placed decarbonization strategies, and their potentially negative consequences for firms' costs and competitiveness, at the centre of the European policy debate. We evaluate the relevance of energy policies for competitiveness by augmenting the standard analysis, largely based on labour costs, with a Unit Energy Cost (UEC) indicator. We analyse how the UEC evolved in different countries and industries and we assess its main drivers (prices, energy intensity, sector composition). Modelling the relationship between foreign sales and the UEC in a gravity model setup, we find that an increase in UECs reduces bilateral exports; the largest negative effects are obtained when limiting the analysis to euro-area countries. Our results strengthen the case for pursuing further integration of European energy markets (as provided for in the Energy Union and Winter packages) to ensure that the ambitious long-term European decarbonization targets do not have a negative impact on the euro-area industry's ability to compete worldwide.
\end{abstract}

JEL Classification: C53, D24, Q41.

Keywords: firms' costs, energy, competitiveness, decarbonization, EMU.

DOI: $10.32057 / 0$. TD.2020.1259

\section{Contents}

1. Introduction .5

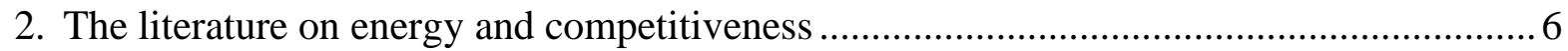

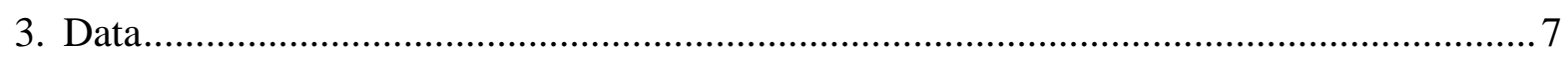

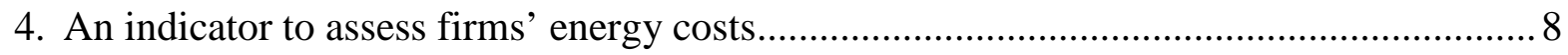

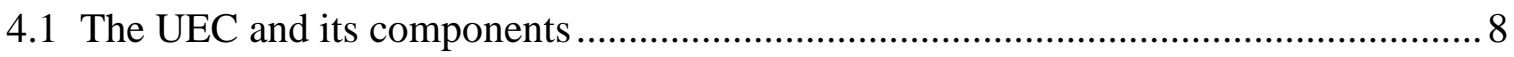

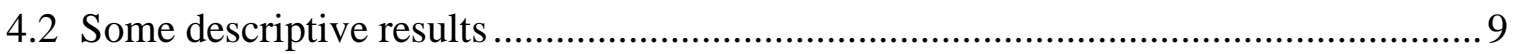

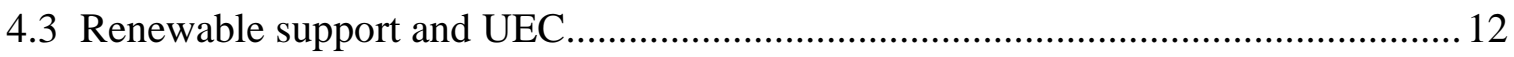

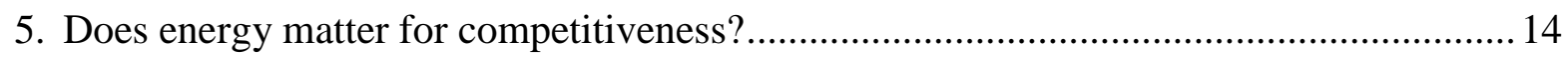

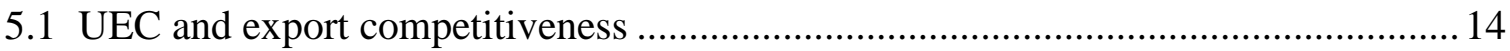

5.2 The European Monetary Union as a natural experiment......................................... 16

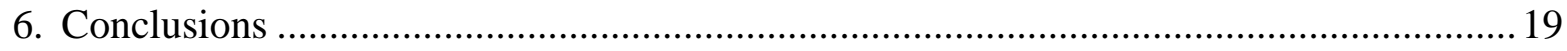

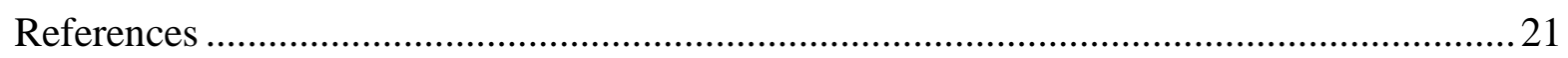

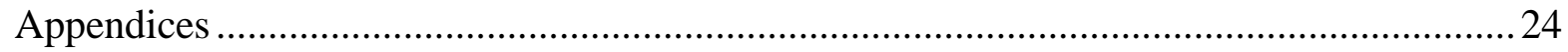

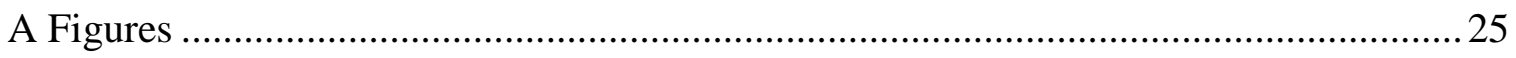

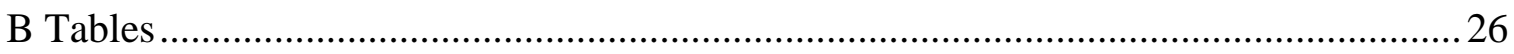

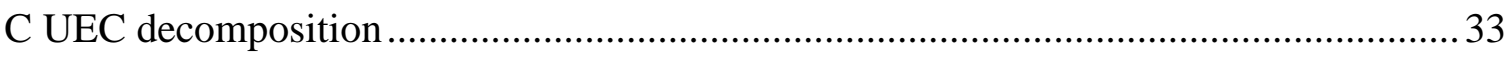

\footnotetext{
* Bank of Italy, Directorate General for Economics, Statistics and Research.
} 



\section{Introduction 1}

The European business community regularly raises the issue of a growing gap in energy prices compared with the global competitors (e.g. US and China) that could hamper the competitiveness of many industrial activities, blaming the European decarbonization strategy and an overcautious approach in harnessing unconventional hydrocarbons (European Commission 2014b).

Also some European institutions are expressing their concern for the effect that ever-increasing energy prices can have on households' energy poverty and on the competitiveness of European firms. According to the European Competitiveness Report 2014, electricity prices for industrial use are, in Europe, twice than in the US (gas prices three times).(European Commission 2014a)

EU climate and energy policies (Europe 2020, the Energy Union, the Winter package and,recently, the Green New Deal for Europe) will plausibly involve a further rise in energy prices (for the extra-costs of a full-fledged EU ETS, of further renewable subsidization or renewable-related system costs, carbon taxation, etc.) with a potential detrimental effect on European industry competitiveness $2^{2}$

Nonetheless the relevance of this issue, European statistics on business energy costs are scant, irregular and with a very limited level of disaggregation. This data gap hinders the understanding of the link between energy costs and firms' features such as sector specialization, mark-ups' and, in general, firms' ability to compete on the international markets.

The situation is different for labour costs: for example Unit Labour Cost (ULC) is one of the indicators monitored by the Country Macroeconomic Imbalance Procedure - (MIP) - of the European Commission 3 .

We think that energy deserves the same attention and therefore we propose a new formulation of the Unit Energy Cost (UEC), first suggested by Andersen and Ekins (2009).

To estimate this indicator we merge Eurostat data - at a year*country*sector level - covering information on production, value added and energy mix fro all EU countries. We also resort to the information on energy prices paid by industrial users for gas and power (available only at a year*country level). The availability of this detailed data (with information on single energy sources) allow us to analyse how UEC has evolved in different countries/industries and what have been the main drivers (changes in prices, in energy intensity or sector composition).

In order to understand how UEC can influence industry competitiveness, this set of data is combined with information on external trade of EU countries at the industry level. Using a gravity model, and adopting different specifications and robustness checks, we find a persistent negative relationship between export and UEC: between 1995 and 2015, on average, the increase of energy costs curbed the value of export by almost 2.5 percentage points.

This relationship is stronger when we limit the analysis to euro area (EA) countries. Exploiting the adoption of the euro as a natural experiment who might have affected the pricing strategy of the European manufacturing sector, we find for EA countries a higher negative elasticity of trade to UEC (even higher limiting to intra-EU trade).

\footnotetext{
${ }^{1}$ We would like to thank the participants to the 6th Italian Association of Environmental and Resource Economists (IAERE), to the World Congress of Environmental and Resource Economists (WCERE) conferences, to the eighth edition of the Italian Congress of Econometrics and Empirical Economics (ICEEE) and to the 38th edition of the International Energy Workshop (IEW). We are also indebted to Matteo Bugamelli, Federico Cingano, Paolo Sestito, Stefano Siviero, Roberto Torrini, Roberta Zizza, Francesco Zollino and an anonymous referee for their valuable comments. The views expressed do not necessarily reflect those of the Bank of Italy. E-mail: ivan.faiella@bancaditalia.it; alessandro.mistretta@bancaditalia.it.

${ }^{2}$ According to the 2017 World Energy Outlook, the European Union and Japan are the two regions with the highest electricity prices. Over time, EU electricity prices are predicted to become the highest in the world (see fig 6.26 of IEA, 2017).

${ }^{3}$ The indicators used in the MIP scoreboard to measure price and cost competitiveness are the Real Effective Exchange Rate and the nominal Unit Labour Cost with the addition of the Export Market Share.
} 
The paper is organized as follows. Section 2 recaps the literature on the relationship between energy costs, firms' performance and their ability to sell their products on foreign markets. Section 3 describes the set of data used in the empirical analysis. Section 4 introduces the UEC indicator, detailing its main components and drivers, and assessing the causal link between Renewable Energy Sources incentives and energy costs. In Section 5 we present a set of models with the purpose to shed light on the relationship between energy costs and competitiveness and propose a diff-in-diff econometric strategy in order to investigate if the EMU beneficial effects on trade have been lower for high-UEC countries. Finally, Section 6 concludes.

\section{The literature on energy and competitiveness}

There is a large body of studies on energy costs and firms' performance, focusing on how an increase in energy expenditure might impact investment, profitability, exports, employment or productivity. Many of these analyses assess the side-effects of environmental or energy policies. For example Arlinghaus (2015) reviews the empirical literature on the effects of carbon taxation and EU ETS (the EU cap-and-trade system that limits the emissions of energy intensive industries) on various indicators and finds no significant ex-post adverse effects on competitiveness.

Some of these works uses country panel data with a sector-level disaggregation while others exploit detailed microdata at the firm or plant level.

Among the latter, the results are rather mixed.

A group of studies ascertain a link between energy prices changes and firms' performance. Ratti et al. (2011) observe that a 1 per cent increase in energy prices would reduce investment by 1.2 per cent. Abeberese (2017) finds a connection between electricity costs and firms' productivity growth. According to Rentschler and Kornejew (2017) higher energy prices are correlated with reduced profit margins, though the magnitude of the effect is small and it varies across different types of fuel and industries. Faiella and Mistretta (2015) observe that higher energy expenditure compresses firms' ability to increase their revenue, especially abroad.

Other studies find no association between change in energy costs and firms' results. Martin et al. (2014) find that energy taxes, that affects energy intensity, have no impact on firms' performance. Flues and Lutz (2015) don't detect any correlation among changes in electricity prices, firms' exports and other performance measures. Also Gerster (2017) does not find evidence of short-run effects on firms' gross output, exports and employment. Rammer et al. (2017) use firm-level data for countries featuring similar industry structures but different energy policies and their findings suggest that these policies have no relevant influence on firms' international market position (they explain their results with the evidence that cost effects are neutralised by the adoption of more efficient technologies).

A similar range of uncertainty characterizes the analyses that use sectoral-level data.

Costantini and Mazzanti (2012) find that energy taxes are either neutral or even positively correlated with exports (an evidence of a sort of Porter effect; Porter and van der Linde (1995)). Sato and Dechezleprêtre (2015) observe only a small impact on trade of a change in relative energy prices. Kaltenegger et al. (2017) underline the rising importance of indirect energy costs estimated using the energy embodied in intermediate inputs - in assessing how energy expenditure influences firms' performance given the increasing participation in global value chains.

Our paper exploits the wealth of harmonized information provided yearly by Eurostat on different energy sources, production and gross export at the country and industry level. We propose to use our UEC estimator in order to assess the latest dynamics of energy costs - across different sectors and countries - and how these developments might affect firms' competitiveness. Our study use Sector-level fully comparable data. While controlling for the high degree of 
heterogeneity among firms would require firm-level data, our harmonized dataset is suitable for the purpose of evaluating energy policies and energy costs trends across EU countries.

Finally, even if competitiveness is a multi-dimensional concept that should be assessed using a set of price- and non-price indicators (e.g. firms' profitability as suggested by Amici et al., 2017), in what follows we mainly focus on the former. We are aware of the limits of correlating export performance only to the evolution of costs measures. These indicators should be supplemented with price-based real effective exchange rate indices that perform better in explaining export dynamics (Giordano and Zollino, 2015).

\section{Data}

The idea underlying a Unit Energy Cost (UEC) measure, alike for Unit Labour Cost (ULC), is to develop a simple indicator that provides information on the amount of energy that the average firm needs to produce a unit of output, given the adopted technology and fuel mix.

As the ULC can be expressed as a combination of earnings and labour productivity, also the UEC can be estimated as the ratio of energy prices $P_{e}$ to energy productivity or, equivalently, as the product of prices and energy intensity $\frac{E}{Y}$. The UEC can be expressed as follows:

$U E C=P_{e} \frac{E}{Y}$

Every piece of information used for calculating this indicator is based on Eurostat data and hence it is fully comparable across EU countries; because of data constraints we limit our analysis to the manufacturing sector.

We use National Energy Balances for the information on the energy demanded by each sector in a given year; the information is available at sub-industry level with details on different energy sources 4

Cross-country comparable information on industry prices, released bi-annually, are only available for electricity and natural gas $5^{5}$ The information on output, in nominal terms, is obtained from National Accounts 6

To analyse EU country competitiveness we use Eurostat trade data. Because there is no information available on export at the industry level, we use a dataset that accounts for the bilateral trade at the product level according to the Combined Nomenclature at 8-digits (CN8) classification 7 In particular we collect data for about 18,000 different products and we map the CN8 classification into the Prodcom sectorization thus obtaining trade information at the industry level according to Nace rev. 2, at two digits level, classification 8

\footnotetext{
${ }^{4}$ This dataset reports information on the use of total oil products, natural gas, electricity, derived heat, solid fossil fuels, renewables and waste by these sub-industries: Iron and Steel/Non-Ferrous Metals, Chemical and Petrochemical, Non-Metallic Minerals, Mining and Quarrying, Food and Tobacco, Textile and Leather, Paper Pulp and Print,Transport Equipment, Machinery, Wood and Wood Products, Construction, Non-specified (Industry).

${ }^{5}$ Data are collected for different consumption bands. Since information on the level of consumption in each band is not available, we use the price of the median band.

${ }^{6}$ Data are aggregated according to Nace rev 2. We combine this information to obtain a level of aggregation that is coherent to the one used for energy data.

${ }^{7}$ The Combined Nomenclature $(\mathrm{CN})$ is a tool for classifying goods, set up to meet the requirements both of the Common Customs Tariff and of the EU's external trade statistics. The CN is also used in intra-EU trade statistics.

${ }^{8}$ Prodcom codes are composed by 8 digits where the first 4 are related to the corresponding Nace rev. 2 classification. Using this code we are able to aggregate data at industry level. For more details see http: //ec.europa.eu/eurostat/web/prodcom
} 


\section{An indicator to assess firms' energy costs}

\subsection{The UEC and its components}

As previously illustrated, energy costs are estimated using amount of energy, with specific information on electricity, gas, coal, renewable and oil (available from the National Energy Balances) while energy costs are approximated using the information on electricity and natural gas prices paid by industrial users. Since we don't have price data for every energy source, we impute the missing information using the share of gas and electricity on industry final use. This probably results in an overestimation of the UEC given that the sources excluded from the computation (coal, fuel oil, etc.) are usually cheaper than electricity and natural gas (because of their lower value in terms of flexibility and energy returns); the shrinking trend in the use of these sources should limit the upward bias of our estimates.

The general formula for the UEC is the following:

$$
U E C=\frac{E C}{P R O D} .
$$

This indicator, that expresses total energy costs $(E C)$ as a percentage of the value of production $(P R O D) \sqrt[9]{9}$ can be estimated at different levels of aggregation, allowing us to analyze it at the EU, country or industry level; moreover, it can be easily decomposed in order to identify the main drivers of its dynamics.

Defining $K_{\text {siet }}$ as the quantity of the energy source $e$ used at time $t$ in industry $i$ of country $s$, and $p$ as the price and $\tau$ as the tax and levies; we have:

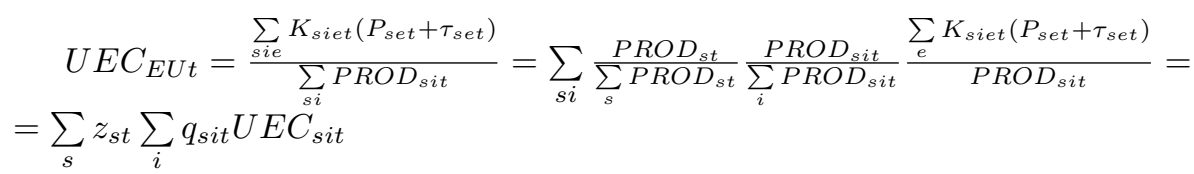

where $q_{s i t}=\frac{P R O D_{s i t}}{\sum_{i} P R O D_{s i t}}$ represents the share of sector $i$ in state $s$ at time $t$ over the whole manufacturing sector and $z_{s t}=\frac{P R O D_{s t}}{\sum_{s} P R O D_{s t}}$ is the share of manufacturing of state $s$ with respect to the total EU manufacturing.

Considering the UEC dynamics at EU level, computed as a difference in percentage points, we can derive the following identities:

$$
\begin{aligned}
& \triangle_{t} U E C_{E U}=\underbrace{\sum_{s} z_{s t-1} \sum_{i} q_{\text {sit-1 }} \sum_{e}\left(\widehat{P}_{\text {siet }-1}+\widehat{\tau}_{\text {set }-1}\right) \triangle_{t} I_{\text {ies }}}_{\text {Energy intensity effect }}+ \\
& +\underbrace{\sum_{s} z_{\text {st-1 }} \sum_{i} q_{\text {sit-1 }} \sum_{e} I_{\text {siet }} \triangle_{t} \widehat{P}_{\text {sie }}}_{\text {Price effect }}+\underbrace{\sum_{s} z_{s t-1} \sum_{i} q_{\text {sit-1 }} \sum_{e} I_{\text {siet }} \triangle_{t} \widehat{\tau}_{\text {se }}}_{\text {tax effect }}+ \\
& +\underbrace{\sum_{s} z_{\text {st-1 }} \sum_{i} U E C_{\text {sit }} \triangle_{t} q_{s i}}_{\text {Sectoral composition effect }}+\underbrace{\sum_{s} U E C_{\text {st }} \triangle_{t} z_{s}}_{\text {Country composition effect }}
\end{aligned}
$$

\footnotetext{
${ }^{9}$ In the paper we follow the suggestions of the European Commission of using a real unit energy costs indicator, defined as energy costs as a fraction of a measure of production (European Commission 2014b).
} 
where prices and taxes are expressed in real terms using the implicit deflator of the production $\left(\widehat{P}_{\text {siet }}\right.$ and $\left.\widehat{\tau}_{\text {set }}\right)$, whereas the $I_{\text {siet }}$ is the energy intensity for a specific country*industry*energy source. The detailed decomposition is available in Appendix C.

According to this decomposition, we can single out 5 drivers: 1) The Intensity effect gives information on how energy efficiency is evolving across different industries; 2) The Price effect accounts for the developments of the unit cost of natural gas and electricity; 3) The Tax effect is similar to the Price effect but focus on taxation and levies only; 4) The Sectoral composition effect describes how changes in industry structure influence total energy costs (e.g. because of the decline/increase of a sector contribution to total production); 5) The Country effect affects the UEC according to the relative weight of different EU economies. The first three drivers can be assessed separately for electricity and gas.

\subsection{Some descriptive results}

In the last decades energy costs became increasingly relevant: UECs almost doubled rising from $3.1 \%$ in 2000 to $4.7 \%$ in 2015 (Figure 1 ).

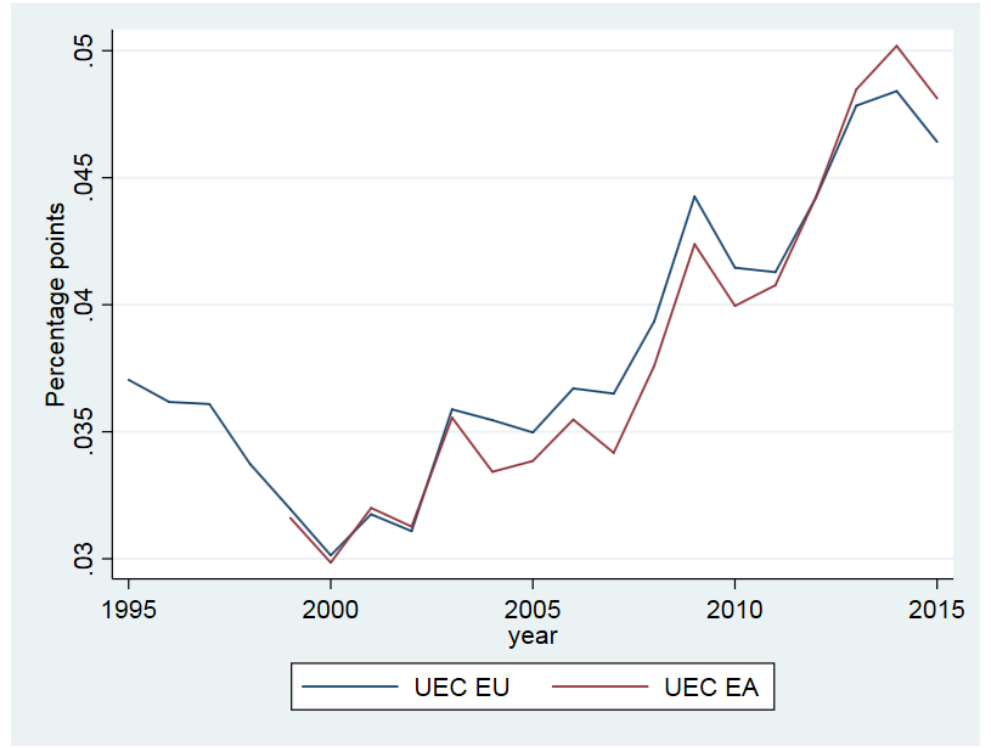

Figure 1. UEC in EU and in EA

To have an idea on UEC dynamics in relative terms one can compare it with the costs of another key input of production, labour. In the first decade of this century energy purchases in the EU manufacturing sector were roughly a seventh of labour cost. This ratio has been constantly increasing in the following years, reaching more than a quarter in the latest period (Figure 2). 


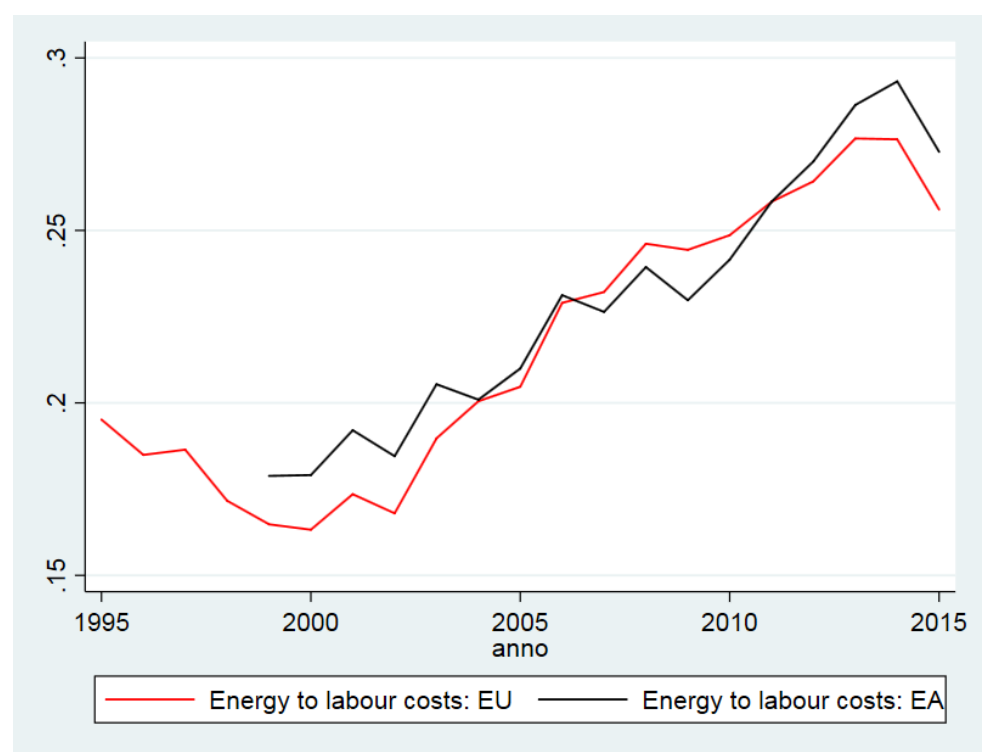

Figure 2. Comparison between UEC and ULC.

If we analyse the UEC by sector, we can see, not surprisingly, that this upward general trend has been mostly driven by energy-intensive sectors, that contribute the most to the EU-level UEC ${ }^{10}$ These are essentially Iron and Steal/Non-Ferrous Materials, Non Metallic Minerals and Paper Pulp and Print (Figure 3).

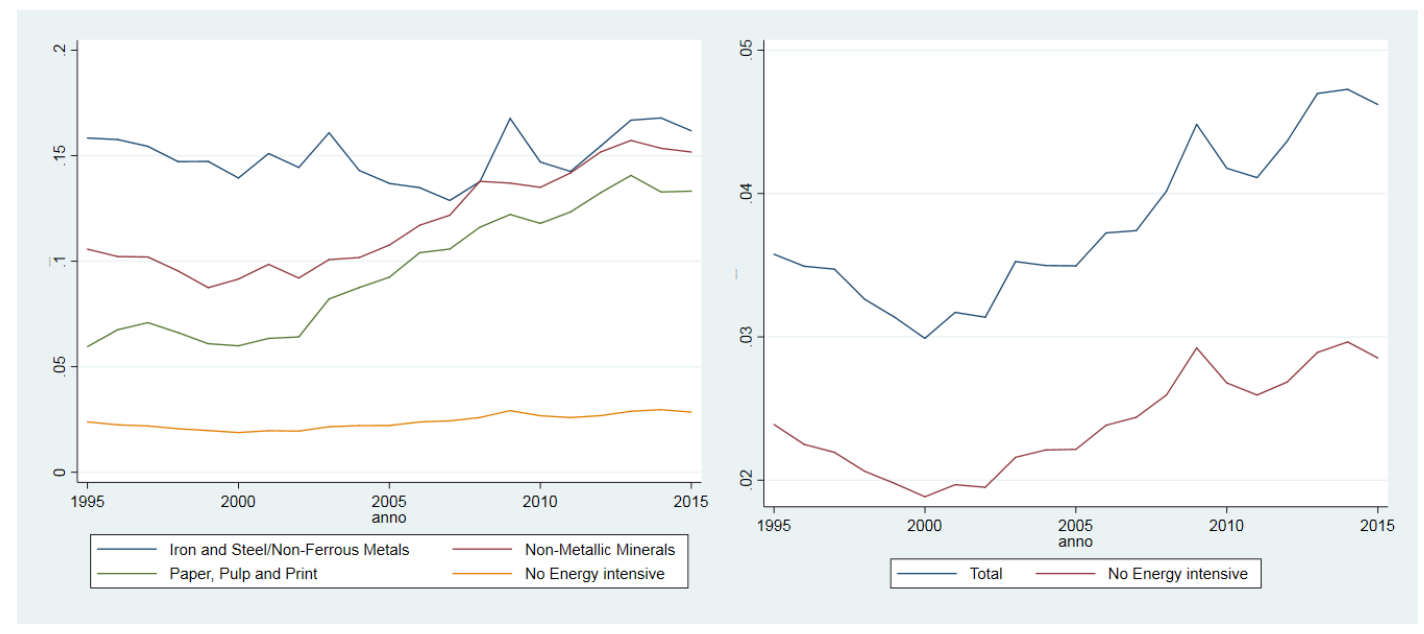

Figure 3. UEC trends by sector

But there is more then the weight of energy intensive-industries that can explain UEC dynamics. In order to understand the role of the different drivers of UEC dynamics we can decompose the different factors, as discussed in Section 3.1, according to their year-on-year contribution (Figure 4).

\footnotetext{
${ }^{10}$ We define Energy Intensive sectors as those with a UEC greater than the 75 th percentile of the country distribution during the whole sample period.
} 
Country composition effect seems to be relevant when new countries accessed the EU, because the UEC of those countries was larger than the EU average 11

Considering prices, until 2001 electricity prices gave a negative contribution to UEC changes, while afterwards it was responsible for most of UEC growth. The opposite is true for electricity intensity, whose contribution to UEC growth has been constantly decreasing (with the only exception of 2003). In more recent years, taxation, in particular that on electricity (that includes also the levies collected to support renewable energy), has becoming increasingly important.

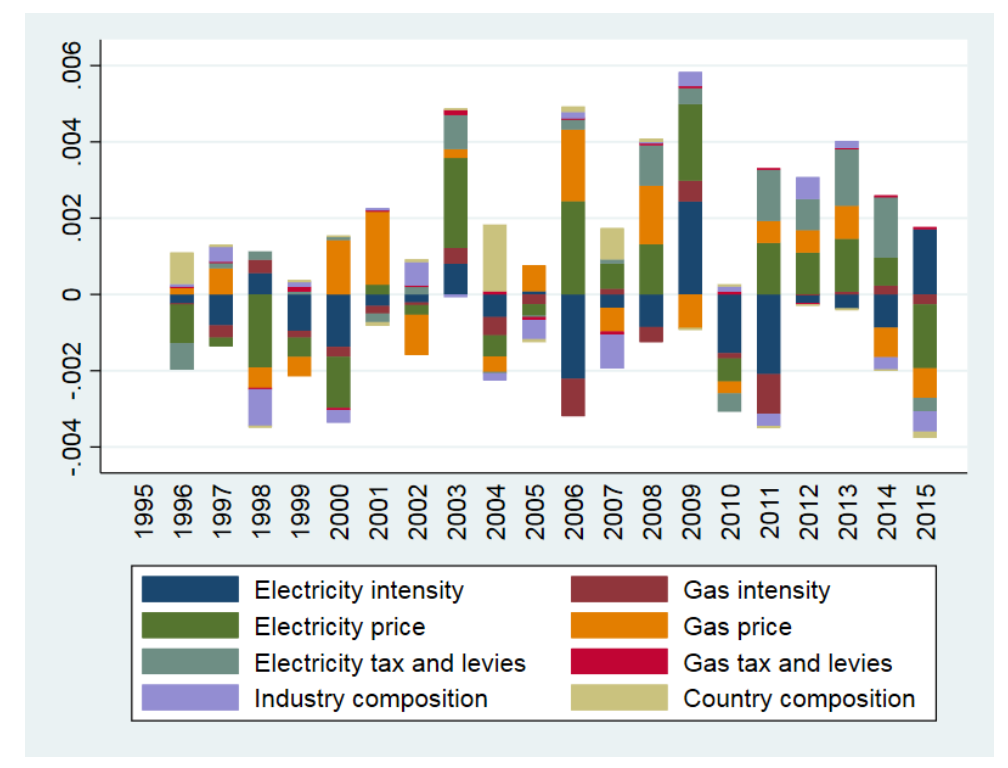

Figure 4. EU UEC dynamics, y-o-y contributions

Finally, the evolution of EU UEC can also be assessed by considering the cumulative growth of its components over the last 20 years. Figure 5 shows that: 1) energy intensity (both for gas and electricity) decreased over time, suggesting a constant improvement in the level of energy efficiency (in particular for gas); 2) pre-tax price dynamics has been particularly important in determining UEC trends; 3) fiscal and parafiscal components (especially for electricity) have played a key role in UEC growth. The observed trends are very similar when we focus on the evolution of the UECs in the bigger EU countries (see figures 9 in Appendix A).

\footnotetext{
${ }^{11}$ From 2004 EU includes Cyprus, Czech Republic, Estonia, Hungary, Latvia, Lithuania, Malta, Poland, Slovakia and Slovenia; from 2007 it also includes Bulgaria and Romania.
} 


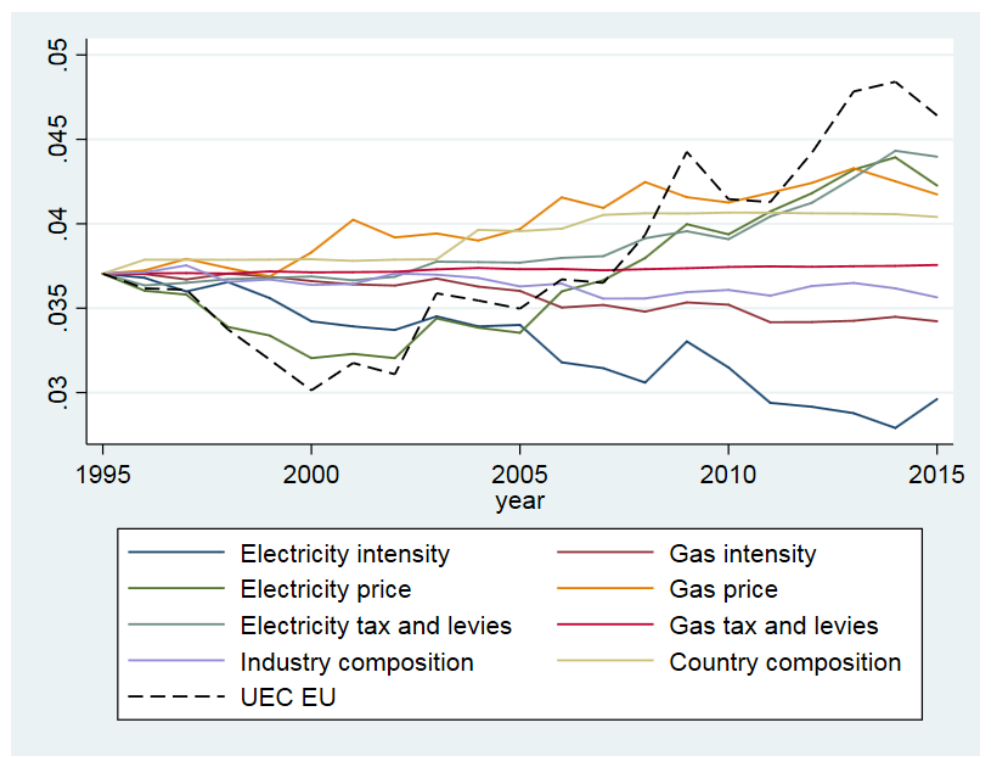

Figure 5. EU UEC, cumulative contributions

If future UEC changes will be governed by the same drivers, EU and National institutions should be aware that a renewed vigour in European climate policies could increase energy costs at the expense of the European manufacturing industry. Without a coordinated global action, higher energy costs could affect the price attractiveness of European goods and this in turn could hamper European competitiveness if there is a negative relationship between energy costs and trade competitiveness; this is what we are going to investigate in Section 4 But since electrification is, together with an increasing role of renewable in the energy mix, one of the major pillars of the European future decarbonisation strategy (European Commission, 2016) we delve more into the relation between Renewable financing and UEC.

\subsection{Renewable support and UEC}

It is useful to elaborate upon the relation among decarbonization, renewable sources, electricity prices and UEC. In the last decade there has been a growing attention to Renewable Energy Sources (RES) as a key strategy to decarbonize the energy systems; this has become a priority since the international agreement on the Kyoto Protocol in 2005. In order to achieve the decarbonization goals envisaged by the Protocol, the EU devised the Europe 2020 strategy that requires specific RES targets: by 2020 RES should contribute to about $20 \%$ to gross final energy consumption and this EU-wide objective has been translated in national targets by each country (burden sharing).

This decarbonization process is having a significant economic impact, in particular in those countries (notably Italy, Germany and Spain) that invested substantially in financing RES deployment: the resources used to pay RES producers are collected through a levy on the use of electricity, thus putting an upward pressure on the electric component of firms' energy expenditure (and, ceteris paribus, increasing their UEC) for the years to come ${ }^{12}$

\footnotetext{
${ }^{12}$ For an evaluation of RES deployment in Italy see Faiella et al., 2016.
} 


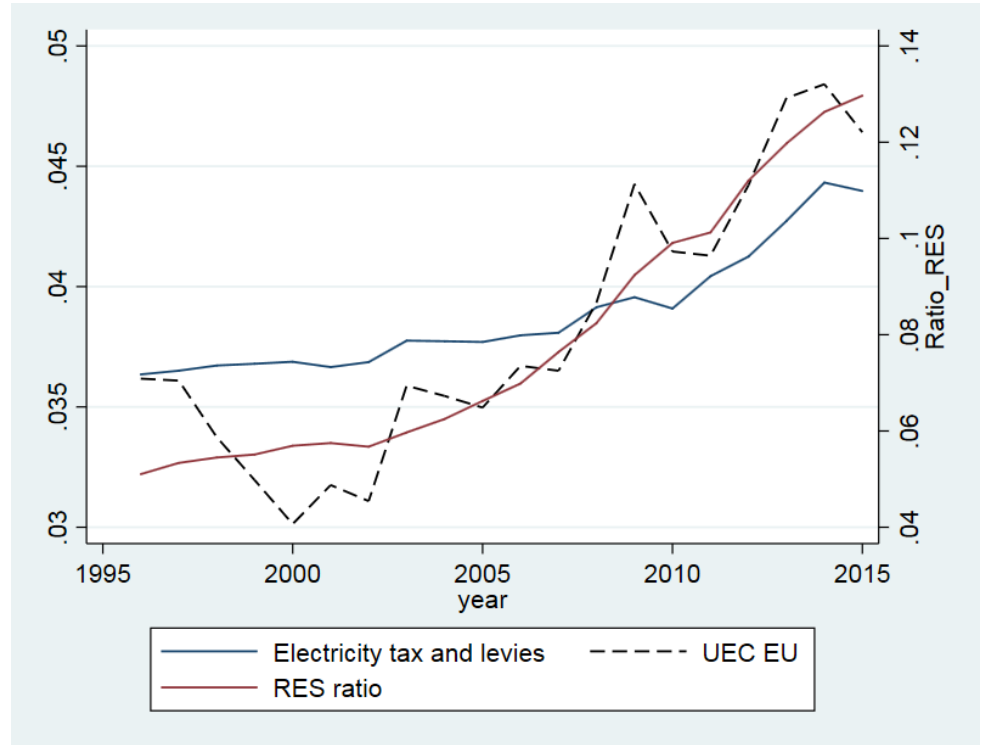

Figure 6. EU UEC, RES deployment and financing

As it is shown in Figure 6 6 it is clear that RES diffusion has pushed electricity levies and consequently UECs.

To better understand the nature of this link we run a set of regressions that explain UEC changes with a measure of how the share of RES in the national power mix affects firms' electricity consumption (RES industry impact) using the following model specification:

$$
\Delta U E C_{i s t}=\alpha+\beta \Delta R E S_{i s t}+\lambda_{i s}+\epsilon_{i s t} .
$$

Because the majority of RES is deployed in the power sector and is financed through electricity levies, this indicator is a proxy of the indirect impact of RES via firms' demand for electricity: in practice the RES industry impact $\left(R E S_{i s t}\right)$ is computed as the product of the share of electricity in the firm energy mix by the RES contribution to the national power energy mix.

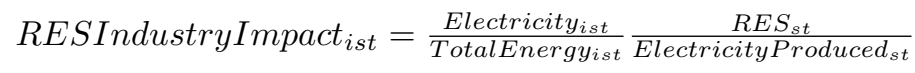

We find a strong association between the dynamic of this measure and UEC (see columns 1 and 5 in Table 21. However, these results could be affected by a reverse causality problem. RES penetration can depend on several factors: the cost of deployment can be different across industries (e.g. because of location or technology constraints) and some sectors may be more exposed to the level and volatility of traditional fuels prices (with an incentive of increasing the proportion of RES into their energy mix). To address this issue we adopt the following IV strategy. Because RES deployment in EU countries is related to the enforcement of the Europe 2020 strategy, the reference target should be exogenous with respect to the single industry of a particular country. Since RES deployment affects energy costs (and therefore the country UEC) these links should be related not only with the notional target but also with the actual effort made in order to achieve it.

We therefore define the variable Achievement ${ }_{s t}$, which is informative on the success of each country $s$ at time $t$ in order to achieve the national Target $s$

$$
\text { Achievement }_{\text {st }}=\frac{\text { RESShare }_{s t}}{\text { Target }_{s}}
$$


Following the approach of Abeberese (2017), who proposed the generation power mix as an instrument for electricity price, we use as instrument for RES industry share dynamics $(\Delta$ RESIndustryImpact ist $)$ an exogenous variable coming from the Europe 2020 targets. In particular we employ the variable $E$ f fort $_{s t}$ - defined as the progression towards the achievement $\left(\right.$ Effort $_{\text {st }}=\Delta$ Achievement $\left._{s t}\right)$ interacted with a dummy for the period in which Europe 2020 rules have become compulsory (columns 2 and 6 in Table 2 and, additionally, the level of the national RES target (see columns 3-4 and 7-8 in Table 2).

According to the results of first stage regressions we can reject the hypotheses of weak instrument for all the specifications adopted (using the standard F test) (Table 3).

This analysis corroborates a causal link between RES deployment and industries' energy cost for European countries: $\triangle R E S$ coefficients range from 0.29 to 0.48 and applying these parameters to Italy in the period 1995-2015 gives a contribution of RES deployment to total UEC growth between a sixth and a fourth. This average effect hides a large heterogeneity among EU countries. It is possible that countries adopted different strategies: for example one country can spread RES costs evenly between firms and households according to their energy use (as in Italy) while an other can shift the financial burden on households (as it happens in Germany). These differences change how RES support influences UEC and in turn how this affects competitiveness, that is the topic of the next section.

\section{Does energy matter for competitiveness?}

As detailed in Section 1, higher energy costs can hamper firms' competitiveness in many ways. In order to explore the nexus with exports, we estimate a gravity model, harnessing a detailed dataset with bilateral trade information for each EU country (described in Section 2). In the model, information about exporters and importers is used with other covariates meant to control for unobserved fixed effects.

\subsection{UEC and export competitiveness}

According to the literature, in order to avoid biased estimators uni-directional, bilateral flows should be considered ${ }^{13}$ and all trade information should be expressed in nominal terms (Baldwin and Taglioni 2006). In this type of models, bilateral export is modelled using a specification in which demand and supply factors are used as controls: typically GDP and population are included among the regressors as well as other variables deemed relevant (e.g. the distance between countries to proxy for trade barriers) 14

Gravity models have been extensively used in the trade literature for their empirical robustness and their explanatory power (Kepaptsoglou, Karlaftis, and Tsamboulas 2010); in the last years this class of models has become the main tool for estimating bilateral trade (Egger and Pfaffermayr 2003).

Since the seminal paper by Santos Silva and Tenreyro (2006), the empirical literature suggests to adopt the Poisson quasi-maximum-likelihood (PQML) method in order to estimate this class of models. This estimation procedure allows to deal with a large number of zero values and with

\footnotetext{
${ }^{13}$ Uni-directional bilateral flows represent the country export: the previous literature used an average between import and export but this might lead to biased estimators.

${ }^{14}$ There is an intense debate regarding the inclusion of fixed effects in panel data analyses: according to Egger and Pfaffermayr (2003), models including bilateral effects dominate those with main effects and a selection of observable time-invariant variables; however, the inclusion of fixed bilateral effects makes it impossible to directly estimate the coefficients of time-invariant observables (like distance).
} 
the presence of a high level of heteroscedasticity, and it performs better in term of bias (Head and Mayer 2014).

As in Santos Silva and Tenreyro (2006), we check for the correct specification of the conditional expectation comparing the model estimated with PQML and with OLS, using a modified RESET test (Ramsey 1969). This test shows the superiority of the PMQL estimator (see Table 4 ).

\section{INSERT HERE TABLE 4}

Using PMQL, we choose the following model specification:

$$
\operatorname{Exp}_{\text {spit }}=\alpha X_{\text {sit }}+\omega W_{p t}+\beta U E C_{\text {sit }}+t_{s}+\lambda_{s p i}+\epsilon_{\text {spit }} .
$$

where $E_{x p} p_{\text {spit }}$ is the uni-directional bilateral trade flowing from country $s$ to country $p$ of goods produced by industry $i$ at time $t$; additionally, $X_{\text {sit }}$ includes controls for the exporter country $(s)$ and $W_{p t}$ for the commercial counterpart $(p)$; additional controls are countries' GDP and population and the sector composition of the considered economy. Moreover, since UEC exploits only information on electricity and natural gas, we also include the share of other energy sources that are consumed at the industry level, the industry-country specific ULC ${ }^{15}$ and the weight of the $i-t h$ sector compared to total manufacturing in country $s$. We also add a fixed effect $\lambda_{s p i}$ at industry-country-partner level and, in order to control for global sectoral shocks, a year*industry dummy $\left(t_{s}\right)$. Additionally, in some specifications we consider the differential elasticity of Export to UEC for energy intensive sectors.

We find a negative relationship, statistically different from zero, between UEC and exports, with an elasticity ranging from 0.07 to $0.09{ }^{16}$ Considering the relative change in UECs in the last decade $(+29 \%$ between 1995 and 2015) this corresponds to an average reduction of export by almost 2.5 percentage points; while in the same timespan the change in the ULC $(-1.5 \%)$ would have increased export by 0.48 percentage points.

\section{INSERT HERE TABLE 6}

For maximising comparability we use Eurostat data preventing us from exploiting information on China, USA and the Rest of the World. For this reason in the first column of Table 6 we don't have counterparts' information as control variables. To disentangle how much our results depend on the sample composition or the controls considered, in column (3) we exclude trade flows to China, USA and the Rest of the World. These results are robust to different specifications of the model and strategies for standard errors computation ${ }^{17}$ Our estimates support, in line with the existing literature (see for example Sato and Dechezlepretre, 2015), the hypothesis that energy costs affects country competitiveness. When only European trade partners are considered (columns (2)-(6) compared to column (1)) our results are even stronger. Results are robust even when we add controls on commercial partners (columns (3)-(6)). Additionally, for energy intensive sectors, our estimates suggest, as expected, a greater response of exports with respect to UEC in columns (4)-(6)). In order to avoid that the energy-intensive parameter is biased by a size-effect we also control for the number of workers employed in the sector. Moreover, since - during the period considered - international trade landscape has drastically changed because of the growing role of China (Caliendo et al., 2015), in columns (7) and (8) we also control for the degree of Chinese goods penetration in the counterpart economies ${ }^{18}$ Finally, we also

\footnotetext{
${ }^{15}$ For the sake of full comparability with UECs we express labor costs as a share of the value of production.

${ }^{16}$ The coefficients reported in Tables are estimated with a PQML and as such they can be interpreted as elasticities. See Gourieroux, (2000).

${ }^{17}$ Considering the bilateral exchange rate among the covariates does not impact significantly our results. These set of estimates are available upon request.

${ }^{18}$ The contribution of the counterpart Chinese import with respect to the total import at the industry level is included as a regressor.
} 
consider industry composition of both exporter countries (columns (1) to (6)) and commercial counterparts (columns (3) to (6)) 19

In all regressions, parameters' estimates have the expected sign and size, in line with the main results in the literature: export increases with GDP (in both importer and exporter countries) and decreases with population size.

There is the possibility that our results are affected by a reverse causality issue: for instance, firms more exposed to the international markets may decide to invest more in energy efficiency in order to reduce their UECs. Although this effect is plausible, the process of incorporating energyefficient technologies impacts all the other industrial processes and takes times to be completed. We check the robustness of our results to this issue using a bi-annual dataset and assessing the impact of the UEC in a 4-years time span. In particular we average our original data over two years and we estimate the same set of models on this collapsed dataset (see columns (1)-(5) of Table 7); additionally we use lagged UECs as a proxy of the current UECs (columns (6)-(10) of Table 7). Also in this case our results corroborate the hypothesis that energy costs depress exports and, again, this effect is stronger when we limit the analysis to EU countries.

\subsection{The European Monetary Union as a natural experiment}

To better understand the link between energy costs and competitiveness we exploit the adoption of the euro as a specific event who might have affected the pricing strategy of the manufacturing firms in the European Monetary Union (EMU) (see for example Bayoumi et al., 2011).

Within a monetary union, the rebalancing of countries with current account deficits requires deflationary adjustment such as fiscal contraction and/or internal devaluation. The literature on internal devaluation usually considers differences in ULCs and finds that countries with lower labour costs exhibit an higher degree of competitiveness. In particular, Myant et al. (2016) observe that during the double-dip recession internal devaluation has been used in order to reduce current account imbalances; Angelini et al. (2015) compare the experiences of internal devaluation in Germany and Spain and find that lower wage and price mark-ups led to an increase in competitiveness; Stockhammer and Sotiropoulos (2014) estimate the effect of domestic demand and ULC on current account, in order to assess the costs of internal devaluation.

Applying these findings to our analysis, a persistent rise in energy prices can give a comparative advantage to countries with lower and more stable UECs. The difference in UECs can be ascribed to several factors, e.g. lower-UEC can be the result of domestic energy resources, less ambitious climate and energy policies - relying on cheaper fuels and/or disregarding their effects on the environment - or the fact that some countries shield industrial users from taxation on energy products.

Before studying how UECs affect trade among EA countries, it is important to recall that adopting the euro has boosted per se the trade opportunities within the common currency area. This result is widely corroborated by the literature. Since Glick and Rose (2002) a large body of literature has investigated this issue. Most of the studies have found a large and positive effect on trade; more recently, Glick and Rose (2016) revised downward their results. Rose (2017) provides a short review of the papers on EMU effect on trade ${ }^{20}$ he finds that there are about 45 papers on this topic (with only six reporting negative effects) and that the contribution of EMU to trade growth (that most of the studies estimate in the neighbourhood of $20 \%$ ) varies because

\footnotetext{
${ }^{19}$ We use the share of value added of Agriculture, forestry and fishing; Arts, entertainment and recreation, other service activities, activities of household and extra-territorial organizations and bodies; Construction; Industry (except construction); Information and communication; Professional, scientific and technical activities; administrative and support service activities, Public administration, defense, education, human health and social work activities; Real estate activities; Wholesale and retail trade, transport, accommodation and food service activities.

${ }^{20}$ There are several papers that review this literature like Rose and Stanley (2005) and Havranek (2010).
} 
different countries and years are selected to define the sample. Camarero et al. (2018) find that the effect of the euro on trade has been positive and significant also through the stimulus of foreign direct investments. A different perspective is presented by Mika and Zymek (2017) that, focussing on the experience of countries that recently joined EA, revise the trade benefits of euro membership arguing that estimates from an appropriately specified and estimated gravity equation do not support the notion of a euro effect on trade flows based on the experience of euro adopters to date.

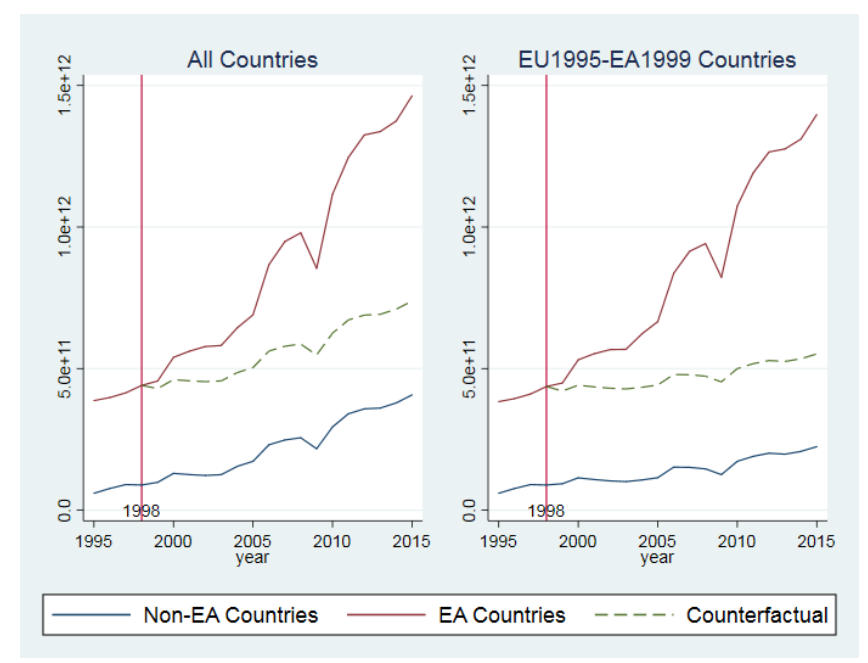

Figure 7. Export (levels)

A graphical inspection confirms the positive impact of joining EA on trade: as Figure 7 shows, the growth in total exports of EA members clearly diverges, compared with that of EU countries that opted out, since 1999 when the Euro was adopted. We find the same pattern for those countries that joined EA since 1999 and for those that joined EU before 1995 (second panel of Figure 7). This result is also substantiated by a pre-treatment common trend test (see Table 5).

This effect is also confirmed by a multivariate analysis: we mantain as in Section 4.1 the structure of our gravity model using socio-economic characteristics of both exporter and importer countries and bilateral fixed effects that absorb time invariant unobserved variables.

Following Santos Silva and Tenreyro (2010), we use a diff-in-diffs approach in a gravity model framework where the treated group includes countries that joined the EA while the control group is composed by the EU countries that didn't join (e.g. the UK, Denmark, Sweden etc...), since these countries are subject to the same institutional setting (the EU trade framework).

In order to strengthen our estimates against the risk of misspecification (e.g some results can be driven by the comparison of manufacturing-based economies with service-based ones), all specifications include the countries' sector compositions.

In line with the empirical literature, in the model we also use as controls a set of interactions of time-dummies together with the bilateral fixed effects, in order to take into account that not all countries joined the EA (the treatment) in the same year. At the same time, because the majority of EA countries adopted the euro in 1999, we also include a common time trend.

We use the following specification:

$$
\operatorname{Exp}_{\text {spit }}=\alpha X_{\text {sit }}+\omega W_{p t}+\beta U E C_{s i t}+\nu E U_{s t}+\theta E U_{p t}+\varphi E A_{s t}+\psi E A_{p t}+t+\lambda_{s p i}+\epsilon_{\text {spit }} .
$$


where $E A_{s t} / E A_{p t}$ is a dummy equal to one if country $s /$ partner $p$ joined the EA at time $\mathrm{t}$ (the same representation is used for the EU dummy). According to this specification $\varphi$ represents the causal effect on export of being part of the EA.

In line with the literature, the estimates corroborate that joining the EA had a positive effect on trade (Table 8): this effect is larger when only intra-EU trade is considered (columns (3)-(8)). As in the previous analysis, we consider export for all counterpart (column (1)-(2)) and then we exclude the Rest of the World, US and China as commercial partners (columns (3) and (9)).

These results are confirmed in all specification, also when we consider the economic structure of the counterpart economy - column (7) - and also when the China import share effect is considered - column (8). In order to see if the results are somewhat influenced by the presence of countries in the upper tail of the export distribution, we also removed Germany from the group of the treated. The results remain substantially unchanged (see column (9) of Table 8) 21

If the EMU has been beneficial for trade, we want though to examine if the benefit of joining has been lower for high-UEC countries. In practice we explore if the adoption of the euro changed the elasticity of exports to UEC. We then add to the previous model an interaction between $U E C_{\text {sit }}$ and the treatment dummy variables $\left(E A_{s t}\right)$.

The new specification is the following:

$$
\begin{gathered}
E x p_{s p i t}=\alpha X_{s i t}+\omega W_{p t}+\beta U E C_{s i t}+\nu E U_{s t}+\theta E U_{p t}+\varphi E A_{s t}+\psi E A_{p t}+\psi E A_{s} * U E C_{s i t}+ \\
\varrho E U_{s t} * U E C_{s i t}+\rho E U_{p t} * U E C_{s i t}+\phi E A_{s t} * U E C_{s i t}+\pi E A_{p t} * U E C_{s i t}+t+\lambda_{s p i}+\epsilon_{s p i t}
\end{gathered}
$$

where $\phi$ measures how exports change with the interaction between $U E C_{\text {sit }}$ and $E A_{s t}$ : this can be seen both as the differential effect of UEC on export for EA countries or as the benefit of joining the EA, considering the relevance of energy cost in the production.

Table 9 reports the estimates that confirm a differential UEC effect on trade among countries that adopted the Euro. Those that joined the EA show a even more negative elasticity of trade to UEC. This is further amplified if we limit the analysis to intra-EU trade (columns (2)-(8)).

Additionally, to avoid the risk that our results are somehow influenced by a trend (general or industry specific) that links UEC and trade, we include a common time trend (see columns (3) and (5)) and a industry-time trend (see columns (6)-(8)); also these specifications corroborate that UECs matter for international competitiveness 22

For the countries that joined the EMU, the link between exports and UEC is negative and different from zero as shown in Table 9 and in Figure 8 , that displays a non-parametric confidence interval of the estimates derived as follows. First we boostrap 1,000 EA-specific parameters using the model corresponding to column (1) of Table 9; we then fit these coefficients using the UEC observed in the sample; we use the empirical distribution of the fitted values to compute a $95 \%$ confidence interval.

\footnotetext{
${ }^{21}$ Between 1999 and 2015, EA export in nominal terms grew of about 140\%; excluding Germany, EA export would have increased by about $100 \%$ while in the same period German export grew of about $250 \%$.

${ }^{22}$ Shengwu et al. (2017), following Puhani (2012), argue that in case of non-linear models (in particular with a Poisson link function), the interaction parameters cannot be considered as the difference in semi-elasticity and propose a solution to fix this issue; in the bottom of Table 9 we show some estimates of the interactions that uses the same kind of adjustment.

${ }^{23}$ The central line is based on the mean of the replications while the upper and lower bound are computed taking upper and lower 2.5 percent of the empirical distribution.
} 


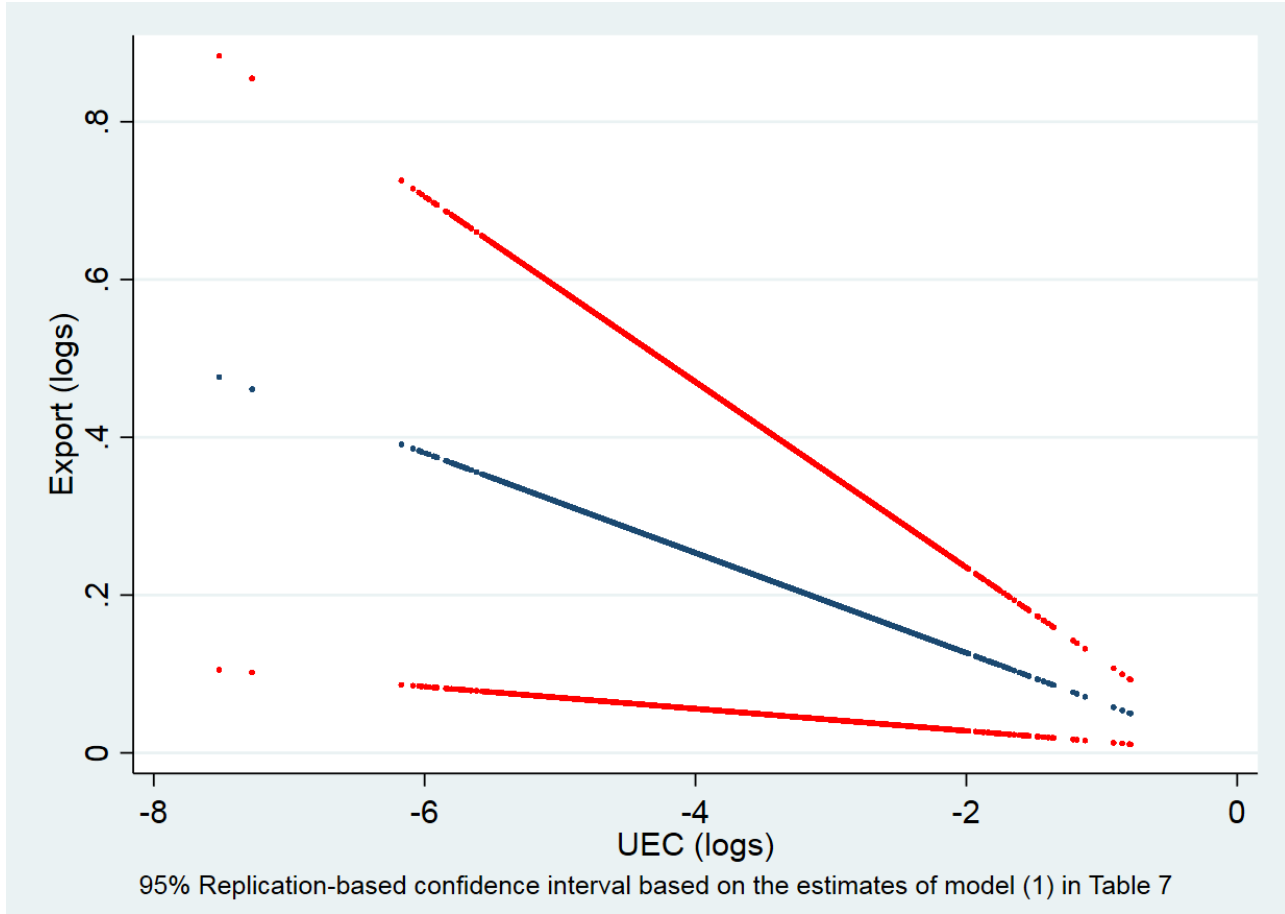

Figure 8. The relationship between export and UEC: differential effect for EA countries

\section{Conclusions}

The EU is the world biggest trader and free trade among its members is one of its founding principles. The Economic and Monetary Union took the European process of economic integration one step further. Moreover, since 2007, the EU started to pursue a common climate and, de facto, energy policy, taking the leadership in the climate arena establishing targets (for climate, renewable energy and energy efficiency) and setting up the biggest cap-and-trade system in the world. Since then, these policies, although lately with less political emphasis, have been reiterated and extended to 2030 .

How these different strategies interact is not completely understood. EU climate and energy policies are putting upward pressure on energy prices (for the extra-costs implied by a fullfledged EU ETS, RES subsidization and carbon taxation) with a potential detrimental effect on the competitiveness of the European industry. But on the other hand the EMU has shielded the EA members from the price spike occurred in the first decade of the 2000.

In order to study the drivers of energy costs and the link between their dynamics and export we propose a new formulation of the Unit Energy Cost (UEC). To estimate this indicator we merge Eurostat data - at a year* country*sector level - covering information on production, value added and energy mix, energy prices and external trade.

In the first decade of the century energy purchases in the EU manufacturing sector were roughly a seventh of labour cost. This ratio has been constantly increasing in the following years, reaching more than a quarter of labour costs in the latest period. The evolution of EU UEC, assessed by considering the cumulative growth of its components in the last 20 years, shows that final prices (mainly driven by their fiscal and parafiscal components) have played a key role 
in sustaining UEC growth, somewhat counterbalanced by an increase in energy efficiency; these trends has been very similar among the bigger EU countries.

We find a causal link between RES deployment and industries' energy cost for European countries, with a large heterogeneity among EU countries: in case of Italy in the period 19952015 the contribution of RES deployment to total UEC growth has been between a sixth and a fourth. If the effects of future energy and climate policies on UECs will be similar of what happened in the past we can expect that EU manufacturing sector will be seriously impacted unless analogous initiatives are adopted across the board at the global level, such as the carbon border tax that re-entered in the EU policy debate with the Green New Deal proposal. ${ }^{24}$

As it happens for ULC, we suggest to use some kind of energy cost indicator in monitoring country competitiveness: a possibility is to add UEC to the Countries' Macroeconomic Imbalance Procedure (MIP) prepared by the European Commission. This would add information to the current analyses that only asses differences in energy prices (with no clues neither on the quantity of energy used nor on the level or the evolution of energy intensity). Filling this data gap would improve the understanding of the link between energy and climate policies, firms' costs and firms' features such as sector specialization, mark-up and, in general, EU firms' ability to compete on the international markets.

Finally, using a gravity model, we find a negative relationship, statistically different from zero, between UEC and exports, with an elasticity ranging from 0.07 to 0.09 . Considering the relative change in UECs in the last decade $(+29 \%$ between 1995 and 2015) this corresponds to a cumulative reduction of export by almost 2.5 percentage points. Our estimates suggest, as expected, a greater response of exports with respect to UEC in energy intensive sectors.

When evaluating UEC effect on trade among Euro members we find that countries that joined the EMU show a persistently larger elasticity. This can be interpreted as a sign that the benefits of joining the EA, although positive, decrease as energy costs soar.

Our results recall the risk that a long-lasting increase in energy costs can make European products less price-attractive. Therefore, if we want to limit the negative impact that a renovated effort to decarbonize the European economies can have on industrial competitiveness there is the need to push forward the integration of European energy markets (as envisaged in the Energy Union and in the Winter package) ${ }^{25}$ Finally a better coordination of the EU climate and energy policies (such as a common carbon taxation on non-ETS sectors' emissions or a design of common EU incentives to promote energy efficiency) could help in reducing the UEC heterogeneity within the EU.

\footnotetext{
${ }^{24}$ The practical setup of a carbon border adjustment, that does not violate the WTO legal framework, must overcome significant challenges: technical feasibility, data availability, the risk of retaliation (Rocchi, Serrano, Roca, and Arto 2018)

${ }^{25}$ For example the integration of European electricity and gas markets (such as a common European capacity and reserve mechanism) can scale down system costs reducing the need for a large generation capacity (Bockers, Haucap, and Heimeshoff 2013).
} 


\section{References}

Abeberese, A. (2017): "Electricity Cost and Firm Performance: Evidence from India," The Review of Economics and Statistics, 99(5).

Amici, M., E. Bobbio, and R. Torrini (2017): "Patterns of convergence (divergence) in the euro area: profitability versus cost and price indicators," Bank of Italy Occasional Papers, (415).

Andersen, M. S., And P. Ekins (2009): Carbon-energy taxation: lessons from Europe.

Angelini, E., A. Dieppe, and B. Pierluigi (2015): "Modelling internal devaluation experiences in Europe: Rational or learning agents?," Journal of Macroeconomics, 43, 81 - 92.

Arlinghaus, J. (2015): "Impacts of Carbon Prices on Indicators of Competitiveness: A Review of Empirical Finding," OECD Environment Working Papers, (87).

Baldwin, R., and D. Taglioni (2006): "Gravity for Dummies and Dummies for Gravity Equations," (12516).

Bayoumi, T., R. Harmsen, and J. Turunen (2011): "Euro Area Export Performance and Competitiveness," IMF Working Paper, (11).

Bockers, V., J. Haucap, and U. Heimeshoff (2013): "Benefits of an integrated European electricity market," .

Caliendo, L., M. Dvorkin, and F. Parro (2015): "Trade and Labor Market Dynamics: General Equilibrium Analysis of the China Trade Shock," Working Papers 2015-9, Federal Reserve Bank of St. Louis.

Camarero, M., E. Gómez-Herrera, and C. Tamarit (2018): "New Evidence on Trade and FDI: how Large is the Euro Effect?," Open Economies Review, 29(2), 451-467.

Costantini, C., and V. Mazzanti (2012): "On the green and innovative side of trade competitiveness. The impact of environmental policies and innovation on EU exports," Research Policy, 41, 132-153.

Egger, P., and M. Pfaffermayr (2003): "The proper panel econometric specification of the gravity equation: A three-way model with bilateral interaction effects," Empirical Economics, $28(3), 571-580$.

European Commission (2014a): Energy Costs and EU Industrial Competitivenesschap. 6, pp. 185-212. SWD(2014)277.

- (2014b): "Energy prices and costs report," Discussion paper.

(2016): "EU Reference Scenario 2016. Energy, transport and GHG emissions Trends to 2050," Discussion paper.

Faiella, I., A. Bartocci, E. Brodi, A. Felettigh, A. Mistretta, F. Natoli, and L. Painelli (2016): "La Rivoluzione Silenziosa delle Energie Rinnovabili," Mimeograph.

Faiella, I., And A. Mistretta (2015): "Spesa energetica e competitività delle imprese italiane," Economia Pubblica, 42(3). 
Flues, F., And B. Lutz (2015): "Competitiveness Impacts of the German Electricity Tax," OECD Environment Working Papers, (88).

Gerster, A. (2017): "Do electricity prices matter? Plant-level evidence from German manufacturing," Ruhr Economic Papers 672, RWI - Leibniz-Institut für Wirtschaftsforschung, Ruhr-University Bochum, TU Dortmund University, University of Duisburg-Essen.

Giordano, C., and F. Zollino (2015): "Exploring Price and Non-Price Determinants of Trade Flows in the Largest Euro-Area Countries," ECB Working Paper, (1789).

Glick, R., and A. K. Rose (2002): "Does a currency union affect trade? The time-series evidence," European Economic Review, 46(6), 1125-1151.

(2016): "Currency unions and trade: A post-EMU reassessment," European Economic Review, 87(C), 78-91.

Gourieroux, C. (2000): Econometrics of Qualitative Dependent Variables, Themes in Modern Econometrics. Cambridge University Press.

Havranek, T. (2010): "Rose effect and the euro: is the magic gone?," Review of World Economics, 146(2), 241-261.

HeAD, K., AND T. MaYer (2014): "Chapter 3 - Gravity Equations: Workhorse,Toolkit, and Cookbook," in Handbook of International Economics, ed. by G. Gopinath, E. Helpman, and K. Rogoff, vol. 4 of Handbook of International Economics, pp. 131 - 195. Elsevier.

IEA (2017): "World Energy Outlook," Discussion paper, International Energy Agency, Paris.

Kaltenegger, O., A. Loschel, M. Baikowski, and J. Lingens (2017): "Energy costs in Germany and Europe: An assessment based on a (total real unit) energy cost accounting framework," Energy Policy, 104, 419 - 430.

Kepaptsoglou, K., M. Karlaftis, and D. Tsamboulas (2010): "The Gravity Model Specification for Modeling International Trade Flows and Free Trade Agreement Effects: A 10-Year Review of Empirical Studies," The Open Economics Journal, (3), 1-13.

Martin, R., L. B. de Preux, and U. J. Wagner (2014): "The impact of a carbon tax on manufacturing: Evidence from microdata," Journal of Public Economics, 117, 1-14.

Mika, A., And R. Zymek (2017): "Friends Without Benefits? New EMU Members and the "Euro Effect" on Trade," Discussion paper.

Myant, M., S. Theodoropoulou, and A. Piasna (2016): Unemployment, internal devaluation and labour market deregulation in Europe. European Trade Union Institute.

Porter, M. E., and C. van Der Linde (1995): "Toward a New Conception of the EnvironmentCompetitiveness Relationship," Journal of Economic Perspectives, 9(4), 97-118.

Puhani, P. (2012): "The treatment effect, the cross difference, and the interaction term in nonlinear difference-in-differences models," Economics Letters, 115(1), 85 - 87.

Rammer, C., S. Gottschalk, M. Peneder, M. Wörter, T. Stucki, and S. Arvanitis (2017): "Does energy policy hurt international competitiveness of firms? A comparative study for Germany, Switzerland and Austria," Energy Policy, 109, 154 - 180. 
Ramsey, J. (1969): "Test For Specification Errors in Classical Linear Least Squares Regression Analysis," Journal of the Royal Statistical Society. Series B, 31.

Ratti, R. A., Y. Seol, And K. Yoon (2011): "Relative energy price and investment by European firms," Energy Economics, 33(5).

Rentschler, J., And M. KorneJew (2017): "Energy price variation and competitiveness: Firm level evidence from Indonesia," Energy Economics, 67, 242 - 254.

Rocchi, P., M. Serrano, J. Roca, and I. Arto (2018): "Border Carbon Adjustments Based on Avoided Emissions: Addressing the Challenge of Its Design," Ecological Economics, 145, $126-136$.

Rose, A. K. (2017): "Why do Estimates of the EMU Effect on Trade Vary so Much?," Open Economies Review, 28(1), 1-18.

Rose, A. K., And T. D. Stanley (2005): "A Meta-Analysis of the Effect of Common Currencies on International Trade ," Journal of Economic Surveys, 19(3), 347-365.

Santos Silva, J., And S. Tenreyro (2006): "The Log of Gravity," The Review of Economics and Statistics, 88(4), 641-658. $2(1), 51-74$.

(2010): "Currency Unions in Prospect and Retrospect," Annual Review of Economics,

Sato, M., And A. Dechezlepretre (2015): "Asymmetric industrial energy prices and international trade," Energy Economics, 52, S130 - S141, Frontiers in the Economics of Energy Efficiency.

Shengwu, S., N. ERIK, and F. MaOyong (2017): "Interaction Terms in Poisson and Log Linear Regression Models," Bulletin of Economic Research, 70(1), E89-E96.

Stockhammer, E., and D. P. Sotiropoulos (2014): "Rebalancing the Euro Area: The Costs of Internal Devaluation," Review of Political Economy, 26(2), 210-233. 
Appendices 
A Figures

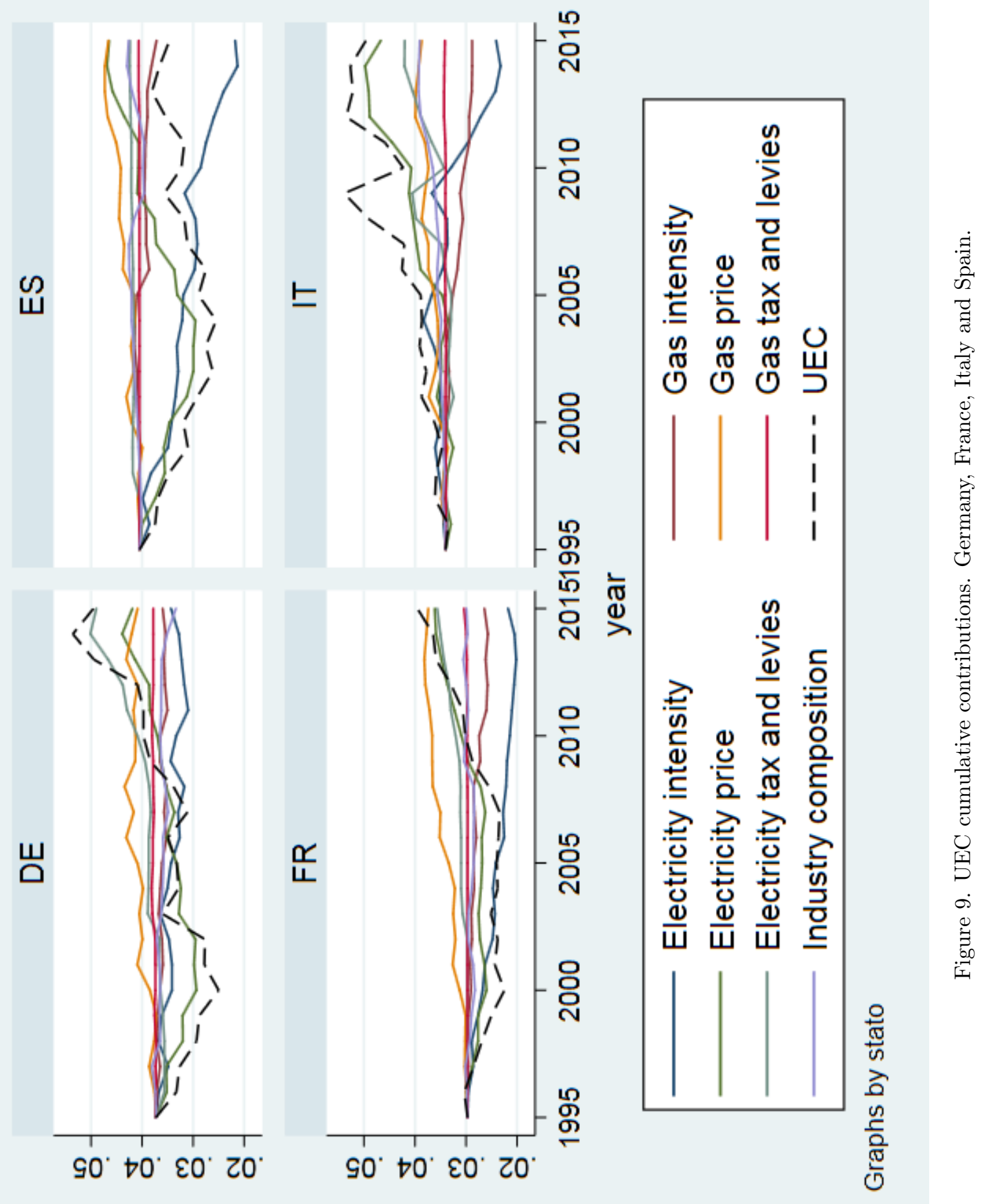


B Tables

Table 1. Descriptive statistics

\begin{tabular}{ccccc}
\hline Year & DE & FR & IT & EU \\
\hline 1995 & 0.0475 & 0.0437 & 0.0416 & 0.0385 \\
& $(0.047)$ & $(0.0467)$ & $(0.0432)$ & $(0.0436)$ \\
1996 & 0.0429 & 0.0447 & 0.0412 & 0.0389 \\
& $(0.0444)$ & $(0.0477)$ & $(0.0444)$ & $(0.0433)$ \\
1997 & 0.0414 & 0.0421 & 0.044 & 0.0385 \\
& $(0.044)$ & $(0.0451)$ & $(0.0475)$ & $(0.0429)$ \\
1998 & 0.0395 & 0.0395 & 0.0442 & 0.0367 \\
& $(0.0418)$ & $(0.0418)$ & $(0.0476)$ & $(0.0404)$ \\
1999 & 0.0389 & 0.0367 & 0.0426 & 0.0354 \\
& $(0.0422)$ & $(0.0377)$ & $(0.0449)$ & $(0.0393)$ \\
2000 & 0.0347 & 0.0344 & 0.0452 & 0.0337 \\
& $(0.0382)$ & $(0.0331)$ & $(0.0476)$ & $(0.0383)$ \\
2001 & 0.0391 & 0.0359 & 0.0483 & 0.0357 \\
& $(0.0423)$ & $(0.0329)$ & $(0.053)$ & $(0.0414)$ \\
2002 & 0.0378 & 0.0347 & 0.0463 & 0.0345 \\
& $(0.0409)$ & $(0.0356)$ & $(0.0492)$ & $(0.0395)$ \\
2003 & 0.0537 & 0.0377 & 0.0478 & 0.0391 \\
& $(0.0546)$ & $(0.0365)$ & $(0.0494)$ & $(0.0444)$ \\
2004 & 0.0514 & 0.0373 & 0.0484 & 0.0385 \\
& $(0.0455)$ & $(0.0351)$ & $(0.0479)$ & $(0.0417)$ \\
2005 & 0.0522 & 0.0358 & 0.048 & 0.0388 \\
& $(0.0444)$ & $(0.0342)$ & $(0.0465)$ & $(0.0418)$ \\
2006 & 0.0533 & 0.0351 & 0.0529 & 0.0412 \\
& $(0.0458)$ & $(0.033)$ & $(0.0488)$ & $(0.0435)$ \\
2007 & 0.05 & 0.0339 & 0.0524 & 0.0421 \\
& $(0.0408)$ & $(0.0306)$ & $(0.0465)$ & $(0.0434)$ \\
2008 & 0.0531 & 0.0355 & 0.0589 & 0.0454 \\
& $(0.0439)$ & $(0.0318)$ & $(0.0529)$ & $(0.0475)$ \\
2009 & 0.0589 & 0.0383 & 0.0647 & 0.05 \\
& $(0.0473)$ & $(0.035)$ & $(0.0581)$ & $(0.0527)$ \\
2010 & 0.0615 & 0.0408 & 0.0512 & 0.0469 \\
& $(0.0495)$ & $(0.0366)$ & $(0.0464)$ & $(0.0491)$ \\
2011 & 0.063 & 0.0442 & 0.0552 & 0.0471 \\
& $(0.049)$ & $(0.0385)$ & $(0.0524)$ & $(0.0499)$ \\
2012 & 0.0638 & 0.0471 & 0.0629 & 0.0501 \\
& $(0.0497)$ & $(0.0419)$ & $(0.0625)$ & $(0.0539)$ \\
2013 & 0.0771 & 0.0505 & 0.0603 & 0.0533 \\
& $(0.0622)$ & $(0.0447)$ & $(0.0569)$ & $(0.0572)$ \\
2014 & 0.0863 & 0.0522 & 0.0615 & 0.0532 \\
& $(0.0701)$ & $(0.0484)$ & $(0.0566)$ & $(0.0566)$ \\
2015 & 0.0831 & 0.0584 & 0.0597 & 0.0526 \\
& $(0.0674)$ & $(0.0555)$ & $(0.0558)$ & $(0.0552)$ \\
\hline & & & \\
& &
\end{tabular}

Mean and Std. dev (in brackets) of UEC at the industry level. 
Table 2. UEC and Renewable Energy Sources (RES)

\begin{tabular}{lcccccccc}
\hline \hline & $(1)$ & $(2)$ & $(3)$ & $(4)$ & $(5)$ & $(6)$ & $(7)$ & $(8)$ \\
\hline$\Delta$ Res & $.0479^{* * *}$ & $.0353^{* * *}$ & $.0339^{* * *}$ & $.0298^{* * *}$ & .0479 & $.0353^{* *}$ & $.0339^{*}$ & $.0298^{*}$ \\
& $(0.01)$ & $(0.00)$ & $(0.00)$ & $(0.00)$ & $(0.13)$ & $(0.04)$ & $(0.05)$ & $(0.07)$ \\
\hline $\mathrm{N}$ & 10,903 & 10,903 & 10,903 & 10,903 & 10,903 & 10,903 & 10,903 & 10,903 \\
$\mathrm{r} 2$ & .0629 & .0332 & .0329 & .0608 & .0629 & .0332 & .0329 & .0608 \\
$\mathrm{fe}$ & yes & no & no & yes & yes & no & no & yes \\
method & OLS & 2 SLS & 2 SLS & 2SLS & OLS & 2SLS & 2SLS & 2 SLS \\
SE cluster & id & id & id & id & country & country & country & country \\
\hline \hline
\end{tabular}

$p$-values in parentheses

Dependent variable is the $\triangle U E C$ in percetage points. All regressions include a country-specific quadratic trend. Cols (1) and (5) report OLS estimates. Cols (2)-(4) as (6)-(8) show IV 2SLS estimates. Models (2) and (6) use the share of RES at time t over the share of RES 2020 target as an instrument; models (3), (4), (7)-(8) add as an instrument the share of 2020 RES target. In all specifications weak instrument hypothesis is rejected.

${ }^{*} p<0.10,{ }^{* *} p<0.05,{ }^{* * *} p<0.01$

Table 3. UEC and RES: first stage regression

\begin{tabular}{lcccccc}
\hline \hline & $(1)$ & $(2)$ & $(3)$ & $(4)$ & $(5)$ & $(6)$ \\
\hline Effort & $.287^{* * *}$ & $.29^{* * *}$ & $.304^{* * *}$ & $.287^{* * *}$ & $.29^{* * *}$ & $.304^{* * *}$ \\
& $(0.00)$ & $(0.00)$ & $(0.00)$ & $(0.00)$ & $(0.00)$ & $(0.00)$ \\
Dummy2010 & & $.00401^{* * *}$ & $.00551^{* * *}$ & & .00401 & .00551 \\
Effort*Dummy2010 & & $(0.00)$ & $(0.00)$ & & $(0.29)$ & $(0.13)$ \\
& & .00189 & -.00532 & & .00189 & -.00532 \\
target & & $.0152^{* * *}$ & -.0442 & & $(0.97)$ & $(0.93)$ \\
& & $(0.00)$ & $(1.00)$ & & $.0152^{* *}$ & $-.0442^{*}$ \\
Col 2 stage & 2 & 3 & 4 & 6 & 7 & $(0.03)$ \\
$\mathrm{N}$ & 10,903 & 10,903 & 10,903 & 10,903 & 10,903 & 10,903 \\
r2 & .34 & .343 & .373 & .34 & .343 & .373 \\
fe & no & no & yes & no & no & yes \\
F & 429 & 132 & 146 & 29.4 & 19.7 & 22.5 \\
SE cluster & id & id & id & country & country & country \\
\hline \hline
\end{tabular}

$p$-values in parentheses

Dependent variable is the $\Delta$ ResIndustryShare in percentage points. All regressions include a countryspecific quadratic trend.

${ }^{*} p<0.10,{ }^{* *} p<0.05,{ }^{* * *} p<0.01$ 
Table 4. Reset Test

\begin{tabular}{lcc}
\hline \hline & OLS & PQML \\
& $\log \left(y_{i t}+1\right)$ & $y_{i t}$ \\
\hline $\mathrm{N}$ & 322,205 & 322,205 \\
Reset Test & 0.0000 & 0.3649 \\
Effects & & \\
year & yes & yes \\
fe & yes & yes \\
$\mathrm{SE}$ & cluster id & cluster id \\
\hline \hline
\end{tabular}

Because of the large mass of zeros in export data, we transform the dependent variable used in the OLS estimation as follows $\log \left(y_{i t}+1\right)$.

Table 5. Pre-treatment common trend test

\begin{tabular}{lcc}
\hline & PMQL $(1)$ & PMQL $(2)$ \\
\hline EA & .144 & .144 \\
& $(0.798)$ & $(0.759)$ \\
EA*1995 & - & - \\
& - & - \\
EA*1996 & .195 & .195 \\
& $(0.291)$ & $(0.203)$ \\
EA*1997 & .0658 & .0658 \\
& $(0.741)$ & $(0.712)$ \\
EA*1998 & .143 & .143 \\
& $(0.483)$ & $(0.436)$ \\
\hline N & 35,955 & 35,955 \\
Effects & & \\
year & yes & yes \\
SE clustered by & Exporting country & Exporting country-Counterparts \\
\hline \hline
\end{tabular}

EA is a dummy equal to one for countries belong to treated group. $p$-values in parentheses 


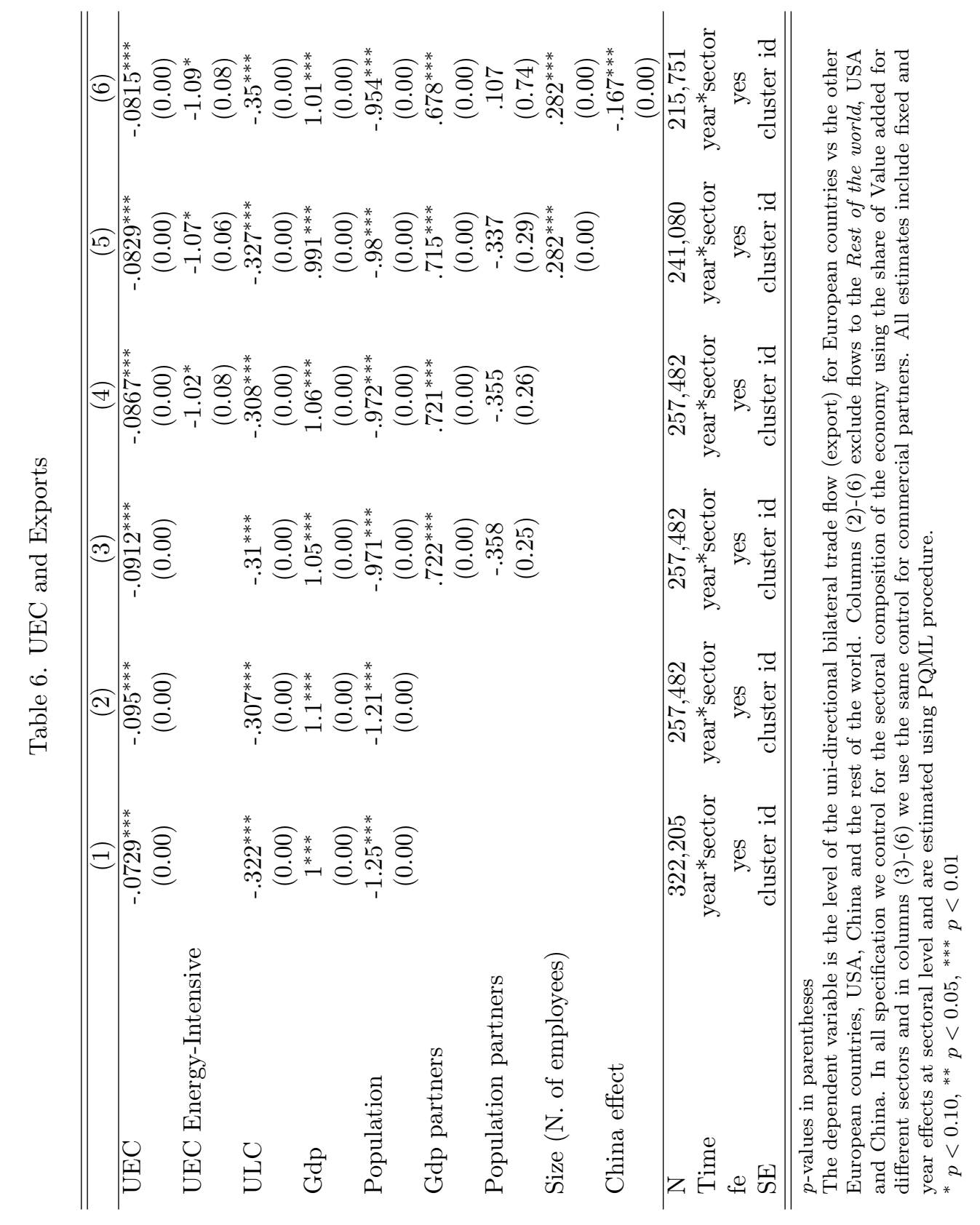




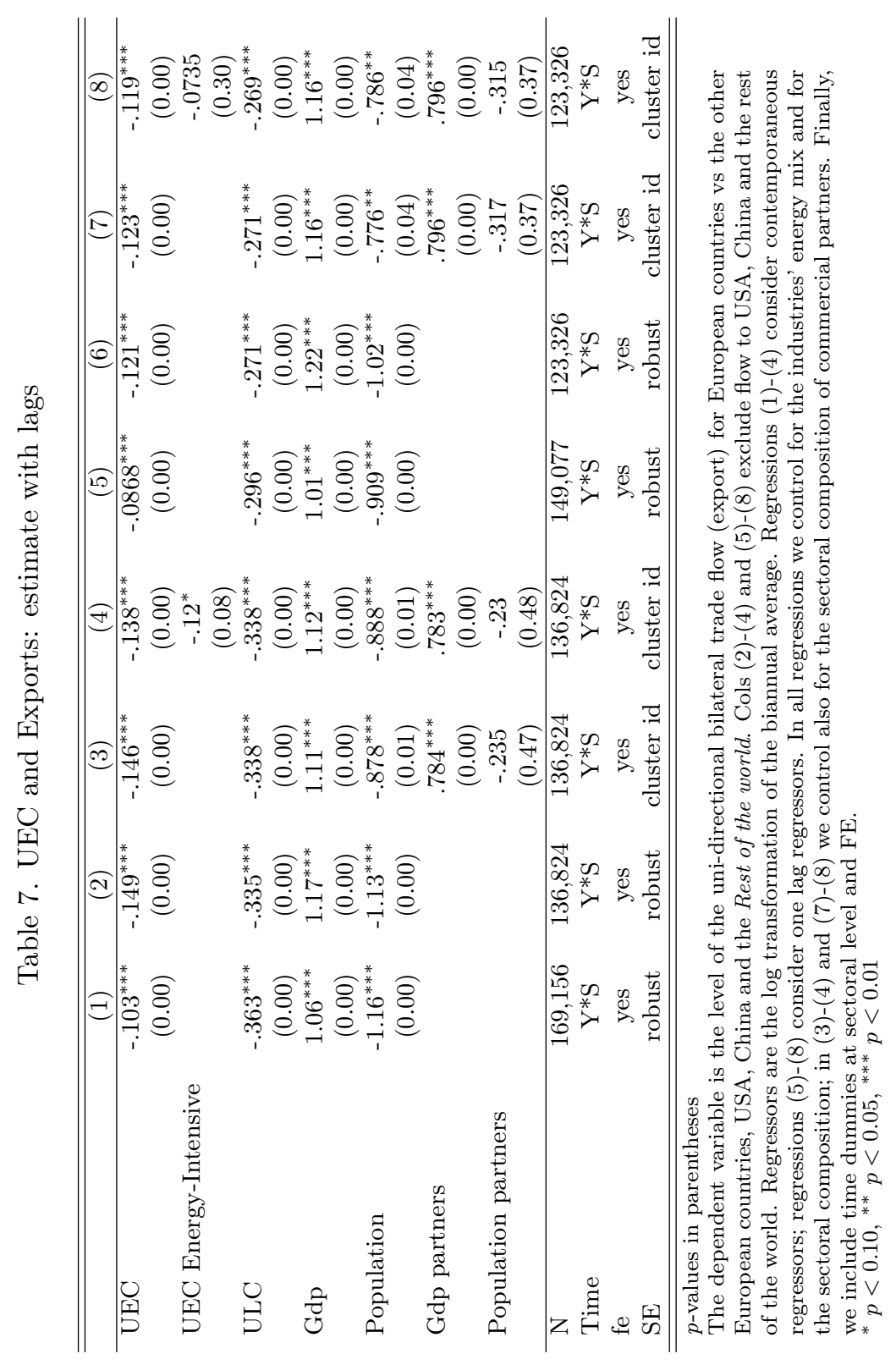




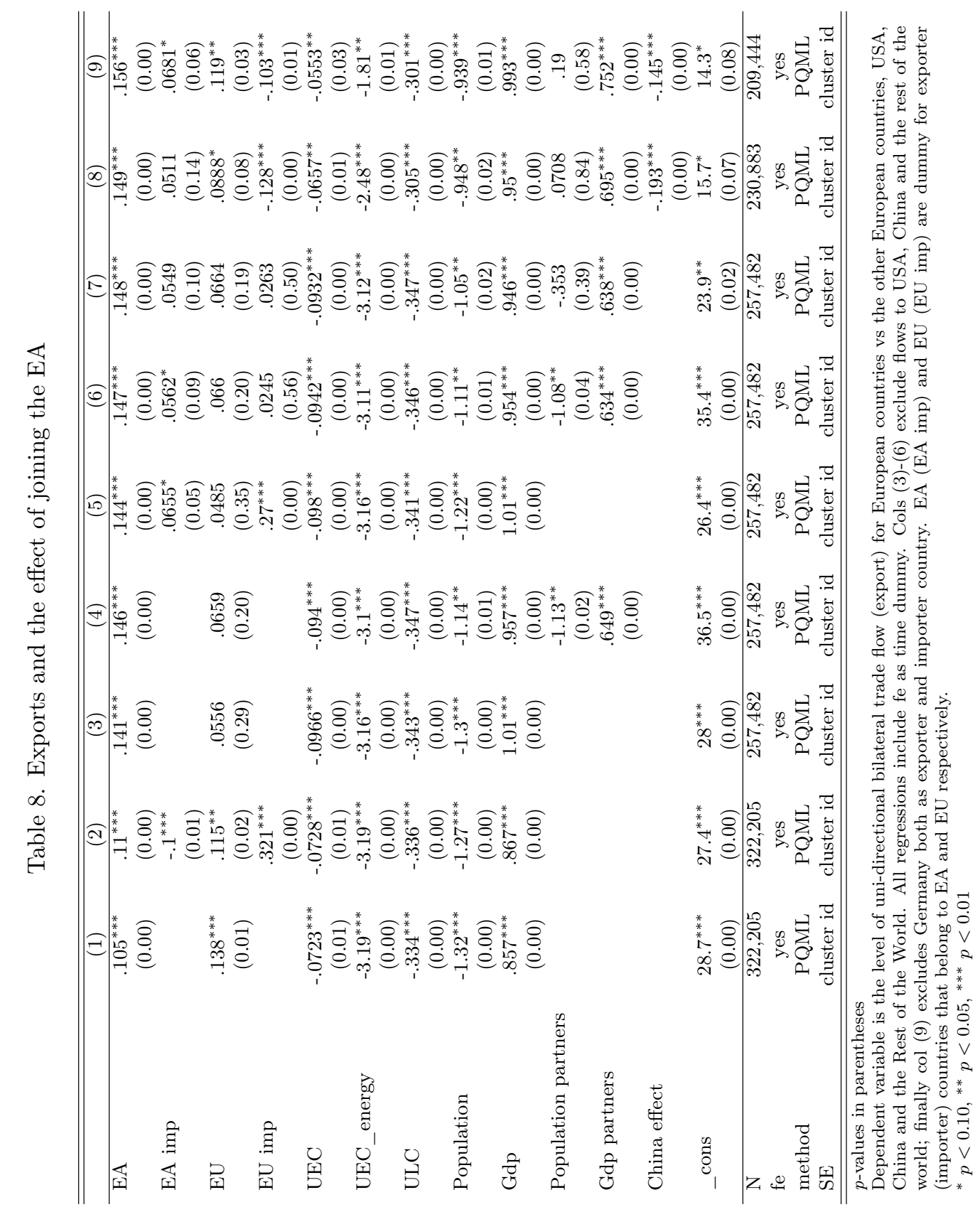




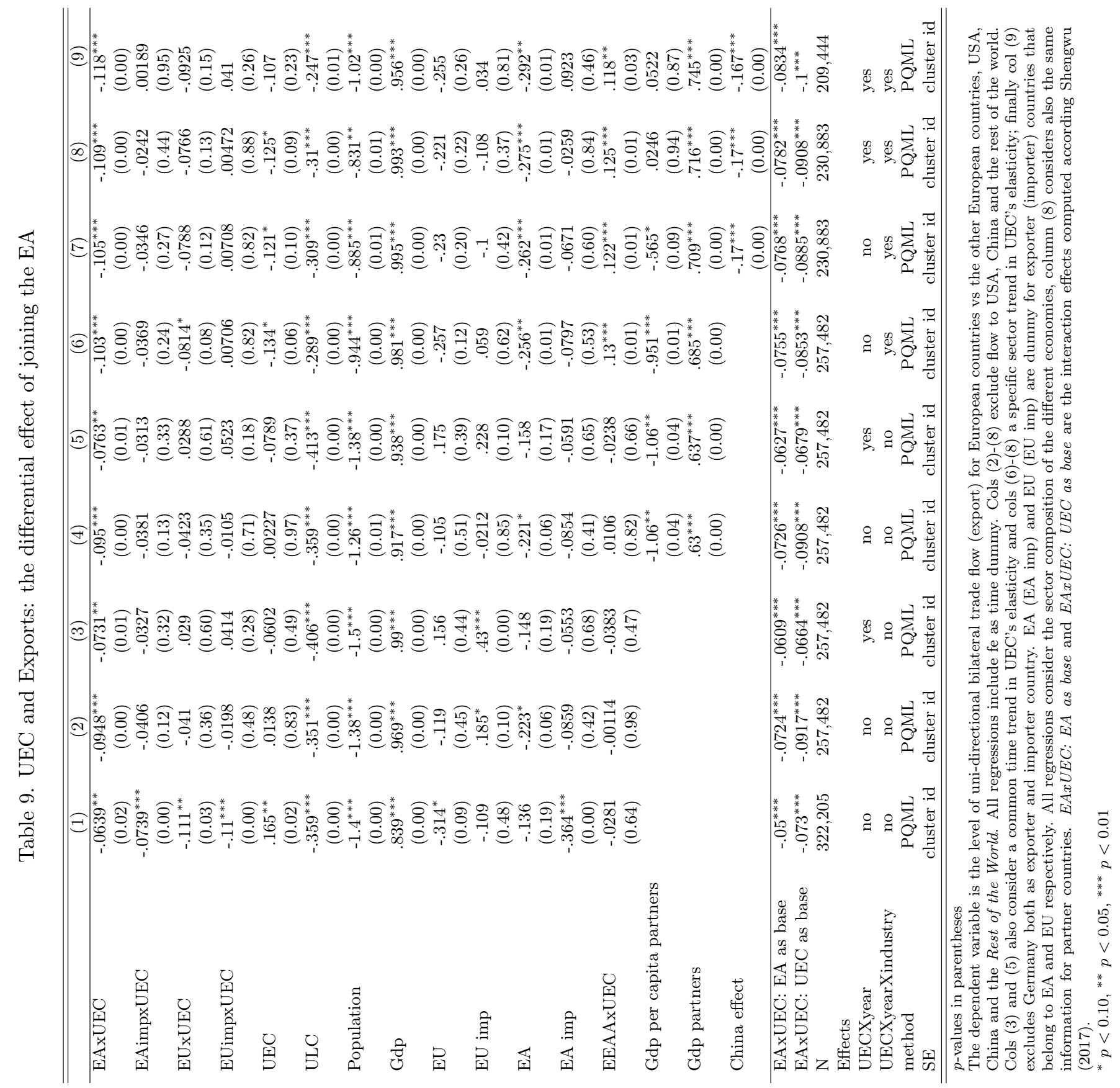




\section{UEC decomposition}

$$
\begin{aligned}
& \triangle_{t} U E C_{s i}=U E C_{s i t}-U E C_{s i t-1}=
\end{aligned}
$$

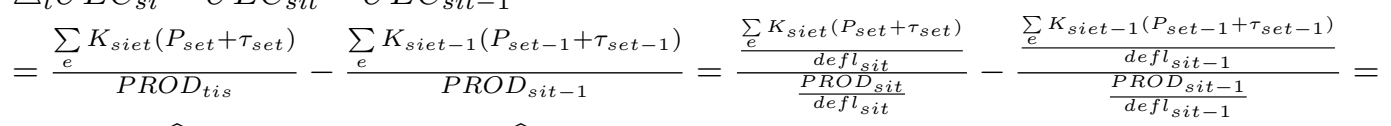

$$
\begin{aligned}
& =\frac{\sum_{e} K_{\text {siet }}\left(\widehat{P}_{\text {siet }}+\widehat{T}_{\text {siet }}\right)}{\widehat{P R O D}_{t i s}}-\frac{\sum_{e} K_{\text {siet }-1}\left(\widehat{P}_{\text {siet }-1}+\widehat{\tau}_{\text {siet }-1}\right)}{\widehat{P R O D}_{\text {sit }-1}} \\
& \text { where } \widehat{P}_{\text {siet }}=\frac{P_{\text {set }}}{\text { defl }} ; \widehat{P}_{\text {siet }}=\widehat{P}_{\text {siet }-1}+\triangle_{t} \widehat{P}_{\text {sie }} ; \\
& \widehat{\tau}_{\text {siet }}=\widehat{\tau}_{\text {siet }-1}+\triangle_{t} \widehat{\tau}_{\text {sie }} \text { and } \widehat{P R O D}_{\text {sit }}=\frac{P R O D_{\text {sit }}}{\text { defl } l_{\text {sit }}} \\
& \text { we define energy intensity as } I_{\text {sit }}=\frac{\sum_{e} K_{\text {siet }}}{P R O D_{t i s}} \\
& =\sum_{e} I_{\text {siet }}\left(\widehat{P}_{\text {siet }-1}+\triangle_{t} \widehat{P}_{\text {sie }}+\widehat{\tau}_{\text {siet }-1}+\triangle_{t} \widehat{\tau}_{\text {sie }}\right)-\sum_{e} I_{\text {siet }-1}\left(\widehat{P}_{\text {siet }-1}+\widehat{\tau}_{\text {siet }-1}\right)=\sum_{e}\left(\widehat{P}_{\text {siet }-1}+\right. \\
& \left.\widehat{\tau}_{\text {siet-1 }}\right)\left(I_{\text {siet }}-I_{\text {siet-1 }}\right)+\sum_{e} I_{\text {siet }}\left(\triangle_{t} \widehat{P}_{\text {sie }}+\triangle_{t} \widehat{\tau}_{\text {siet }}\right)=\underbrace{\sum_{e}\left(\widehat{P}_{\text {siet-1 }}+\widehat{\tau}_{\text {siet-1 }}\right) \triangle_{t} I_{\text {ies }}}_{\text {Energy intensity effect }}+ \\
& \underbrace{\sum_{e} I_{\text {siet }} \triangle_{t} \widehat{P}_{\text {sie }}}_{\text {price effect }}+\underbrace{\sum_{e} I_{\text {siet }} \triangle_{t} \widehat{T}_{\text {sie }}}_{\text {tax effect }}=\triangle_{t} U E C_{\text {si }} \\
& \triangle_{t} U E C_{s}=\sum_{i} q_{s i t} U E C_{s i t}-\sum_{i} q_{s i t-1} U E C_{s i t-1}= \\
& =\sum_{i} q_{s i t} U E C_{s i t}+\sum_{i} q_{s i t-1} U E C_{s i t}-\sum_{i} q_{s i t-1} U E C_{s i t}-\sum_{i} q_{s i t-1} U E C_{s i t-1}==\sum_{i} q_{s i t-1}\left(U E C_{s i t}-\right. \\
& \left.U E C_{s i t-1}\right)+\sum_{i} U E C_{s i t}\left(q_{s i t}-q_{s i t-1}\right)= \\
& =\sum_{i} q_{s i t-1} \triangle_{t} U E C_{s i}+\sum_{i} U E C_{s i t} \triangle_{t} q_{s i}=\triangle_{t} U E C_{s} \\
& \triangle_{t} U E C_{E U t}=\sum_{s} z_{s t} U E C_{s t}-\sum_{s} z_{s t-1} U E C_{s t-1}= \\
& =\sum_{s} z_{s t} U E C_{s t}+\sum_{s}^{s} z_{s t-1} U E C_{s t}-\sum_{s} z_{s t-1} U E C_{s t}-\sum_{s} z_{s t-1} U E C_{s t-1}==\sum_{s} z_{s t-1}\left(U E C_{s t}-\right. \\
& \left.U E C_{s t-1}\right)+\sum_{s} U E C_{s t}\left(z_{s t}-z_{s t-1}\right)= \\
& =\sum_{s} z_{s t-1} \triangle_{t} U E C_{s}+\sum_{s} U E C_{s t} \triangle_{t} z_{s}=\triangle_{t} U E C_{E U}
\end{aligned}
$$

plugging in the previous results, we obtain

$$
\begin{gathered}
==\underbrace{\sum_{s} z_{s t-1} \sum_{i} q_{\text {sit-1 }} \sum_{e}\left(\widehat{P}_{\text {siet }-1}+\widehat{\tau}_{\text {set-1 }}\right) \triangle_{t} I_{\text {ies }}}_{\text {Energy intenity effect }}+ \\
+\underbrace{\sum_{s} z_{s t-1} \sum_{i} q_{s i t-1} \sum_{e} I_{\text {siet }} \triangle_{t} \widehat{P}_{\text {sie }}}_{\text {Price effect }}+\underbrace{\sum_{s} z_{s t-1} \sum_{i} q_{\text {sit }-1} \sum_{e} I_{\text {siet }} \triangle_{t} \widehat{\tau}_{\text {se }}}_{\text {tax effect }}+
\end{gathered}
$$


$+\underbrace{\sum_{s} z_{s t-1} \sum_{i} U E C_{\text {sit }} \triangle_{t} q_{s i}}_{\text {Sectoral composition effect }}+\underbrace{\sum_{s} U E C_{s t} \triangle_{t} z_{s}}_{\text {Country composition effect }}=\triangle_{t} U E C_{E U}$ 


\section{RECENTLY PUBLISHED “TEMI” (*)}

N. 1239 - Bank credit, liquidity and firm-level investment: are recessions different?, by Ines Buono and Sara Formai (October 2019).

N. 1240 - Youth drain, entrepreneurship and innovation, by Massimo Anelli, Gaetano Basso, Giuseppe Ippedico and Giovanni Peri (October 2019).

N. 1241 - Fiscal devaluation and labour market frictions in a monetary union, by Lorenzo Burlon, Alessandro Notarpietro and Massimiliano Pisani (October 2019).

N. 1242 - Financial conditions and growth at risk in Italy, by Piergiorgio Alessandri, Leonardo Del Vecchio and Arianna Miglietta (October 2019).

N. 1243 - Cross-country differences in the size of venture capital financing rounds. A machine learning approach, by Marco Taboga (November 2019).

N.1244 - Shifting taxes from labour to consumption: the efficiency-equity trade-off, by Nicola Curci and Marco Savegnago (November 2019).

N.1245 - Credit supply, uncertainty and trust: the role of social capital, by Maddalena Galardo, Maurizio Lozzi and Paolo Emilio Mistrulli (November 2019).

N. 1246 - Financial development and growth in European regions, by Paola Rossi and Diego Scalise (November 2019).

N. 1247 - IMF programs and stigma in Emerging Market Economies, by Claudia Maurini (November 2019).

N.1248 - Loss aversion in housing assessment among Italian homeowners, by Andrea Lamorgese and Dario Pellegrino (November 2019).

N.1249 - Long-term unemployment and subsidies for permanent employment, by Emanuele Ciani, Adele Grompone and Elisabetta Olivieri (November 2019).

N. 1250 - Debt maturity and firm performance: evidence from a quasi-natural experiment, by Antonio Accetturo, Giulia Canzian, Michele Cascarano and Maria Lucia Stefani (November 2019).

N. 1251 - Non-standard monetary policy measures in the new normal, by Anna Bartocci, Alessandro Notarpietro and Massimiliano Pisani (November 2019).

N. 1252 - The cost of steering in financial markets: evidence from the mortgage market, by Leonardo Gambacorta, Luigi Guiso, Paolo Emilio Mistrulli, Andrea Pozzi and Anton Tsoy (December 2019).

N. 1253 - Place-based policy and local TFP, by Giuseppe Albanese, Guido de Blasio and Andrea Locatelli (December 2019).

N.1254 - The effects of bank branch closures on credit relationships, by Iconio Garrì (December 2019).

N. 1255 - The loan cost advantage of public firms and financial market conditions: evidence from the European syndicated loan market, by Raffaele Gallo (December 2019).

N. 1256 - Corporate default forecasting with machine learning, by Mirko Moscatelli, Simone Narizzano, Fabio Parlapiano and Gianluca Viggiano (December 2019).

N.1257 - Labour productivity and the wageless recovery, by Antonio M. Conti, Elisa Guglielminetti and Marianna Riggi (December 2019).

N.1258 - Corporate leverage and monetary policy effectiveness in the Euro area, by Simone Auer, Marco Bernardini and Martina Cecioni (December 2019).

(*) Requests for copies should be sent to:

Banca d'Italia - Servizio Studi di struttura economica e finanziaria - Divisione Biblioteca e Archivio storico - Via Nazionale, 91 - 00184 Rome - (fax 003906 47922059). They are available on the Internet www.bancaditalia.it. 
Accetturo A., V. Di Giacinto, G. Micucci and M. Pagnini, Geography, productivity and trade: does selection explain why some locations are more productive than others?, Journal of Regional Science, v. 58, 5, pp. 949-979, WP 910 (April 2013).

ADAMOPOULOU A. and E. KAYA, Young adults living with their parents and the influence of peers, Oxford Bulletin of Economics and Statistics,v. 80, pp. 689-713, WP 1038 (November 2015).

Andini M., E. Ciani, G. De Blasio, A. D’Ignazio and V. Silvestrini, Targeting with machine learning: an application to a tax rebate program in Italy, Journal of Economic Behavior \& Organization, v. 156, pp. 86-102, WP 1158 (December 2017).

BARONE G., G. DE BLASIO and S. MOCETTI, The real effects of credit crunch in the great recession: evidence from Italian provinces, Regional Science and Urban Economics, v. 70, pp. 352-59, WP 1057 (March 2016).

Belotti F. and G. IlARDi Consistent inference in fixed-effects stochastic frontier models, Journal of Econometrics, v. 202, 2, pp. 161-177, WP 1147 (October 2017).

Berton F., S. Mocetti, A. Presbitero and M. Richiardi, Banks, firms, and jobs, Review of Financial Studies, v.31, 6, pp. 2113-2156, WP 1097 (February 2017).

Bofondi M., L. CARPinelli and E. SETte, Credit supply during a sovereign debt crisis, Journal of the European Economic Association, v.16, 3, pp. 696-729, WP 909 (April 2013).

Bokan N., A. Gerali, S. Gomes, P. JACQuinOt and M. PiSANI, EAGLE-FLI: a macroeconomic model of banking and financial interdependence in the euro area, Economic Modelling, v. 69, C, pp. 249280, WP 1064 (April 2016).

BRILli Y. and M. TONELlo, Does increasing compulsory education reduce or displace adolescent crime? New evidence from administrative and victimization data, CESifo Economic Studies, v. 64, 1, pp. 15-4, WP 1008 (April 2015).

BUONO I. and S. FORMAI The heterogeneous response of domestic sales and exports to bank credit shocks, Journal of International Economics, v. 113, pp. 55-73, WP 1066 (March 2018).

Burlon L., A. Gerali, A. NotarPietro and M. Pisani, Non-standard monetary policy, asset prices and macroprudential policy in a monetary union, Journal of International Money and Finance, v. 88, pp. 25-53, WP 1089 (October 2016).

CARTA F. and M. DE PHLIPPIS, You've Come a long way, baby. Husbands' commuting time and family labour supply, Regional Science and Urban Economics, v. 69, pp. 25-37, WP 1003 (March 2015).

CARTA F. and L. RIZZICA, Early kindergarten, maternal labor supply and children's outcomes: evidence from Italy, Journal of Public Economics, v. 158, pp. 79-102, WP 1030 (October 2015).

Casiraghi M., E. Gaiotti, L. Rodano and A. SECchi, A “Reverse Robin Hood"? The distributional implications of non-standard monetary policy for Italian households, Journal of International Money and Finance, v. 85, pp. 215-235, WP 1077 (July 2016).

CIANI E. and C. DEIANA, No Free lunch, buddy: housing transfers and informal care later in life, Review of Economics of the Household, v.16, 4, pp. 971-1001, WP 1117 (June 2017).

Cipriani M., A. Guarino, G. Guazzarotti, F. Tagliati and S. Fisher, Informational contagion in the laboratory, Review of Finance, v. 22, 3, pp. 877-904, WP 1063 (April 2016).

De Blasio G, S. De Mitri, S. D’Ignazio, P. Finaldi Russo and L. Stoppani, Public guarantees to SME borrowing. A RDD evaluation, Journal of Banking \& Finance, v. 96, pp. 73-86, WP 1111 (April 2017).

Gerali A., A. LocARno, A. NotARPIETRO and M. PISANI, The sovereign crisis and Italy's potential output, Journal of Policy Modeling, v. 40, 2, pp. 418-433, WP 1010 (June 2015).

LIBERATI D., An estimated DSGE model with search and matching frictions in the credit market, International Journal of Monetary Economics and Finance (IJMEF), v. 11, 6, pp. 567-617, WP 986 (November 2014).

LinAREllo A., Direct and indirect effects of trade liberalization: evidence from Chile, Journal of Development Economics, v. 134, pp. 160-175, WP 994 (December 2014).

NAtoli F. and L. SigAlotTi, Tail co-movement in inflation expectations as an indicator of anchoring, International Journal of Central Banking, v. 14, 1, pp. 35-71, WP 1025 (July 2015).

NuCCI F. and M. RigGI, Labor force participation, wage rigidities, and inflation, Journal of Macroeconomics, v. 55, 3 pp. 274-292, WP 1054 (March 2016).

RIGON M. and F. ZANETTI, Optimal monetary policy and fiscal policy interaction in a non_ricardian economy, International Journal of Central Banking, v. 14 3, pp. 389-436, WP 1155 (December 2017). 
SEGURA A., Why did sponsor banks rescue their SIVs?, Review of Finance, v. 22, 2, pp. 661-697, WP 1100 (February 2017).

AlbANESE G., M. CIOFFI and P. TOMMASINO, Legislators' behaviour and electoral rules: evidence from an Italian reform, European Journal of Political Economy, v. 59, pp. 423-444, WP 1135 (September 2017).

Aprigliano V., G. ArdizzI and L. MonTEForte, Using the payment system data to forecast the economic activity, International Journal of Central Banking, v. 15, 4, pp. 55-80, WP 1098 (February 2017).

ARNAUDO D., G. MICUCCI, M. RIGON and P. Rossi, Should I stay or should I go? Firms' mobility across banks in the aftermath of the financial crisis, Italian Economic Journal / Rivista italiana degli economisti, v. 5, 1, pp. 17-37, WP 1086 (October 2016).

BASSO G., F. D’AMURI and G. PERI, Immigrants, labor market dynamics and adjustment to shocks in the euro area, IMF Economic Review, v. 67, 3, pp. 528-572, WP 1195 (November 2018).

BAtini N., G. MelinA and S. Villa, Fiscal buffers, private debt, and recession: the good, the bad and the ugly, Journal of Macroeconomics, v. 62, WP 1186 (July 2018).

Burlon L., A. Notarpietro and M. Pisani, Macroeconomic effects of an open-ended asset purchase programme, Journal of Policy Modeling, v. 41, 6, pp. 1144-1159, WP 1185 (July 2018).

Busetti F. and M. CAIVANO, Low frequency drivers of the real interest rate: empirical evidence for advanced economies, International Finance, v. 22, 2, pp. 171-185, WP 1132 (September 2017).

CAppelletti G., G. GuAzZAROtTi and P. TOMmasino, Tax deferral and mutual fund inflows: evidence from a quasi-natural experiment, Fiscal Studies, v. 40, 2, pp. 211-237, WP 938 (November 2013).

CARDANi R., A. PACCAGNINI and S. VILla, Forecasting with instabilities: an application to DSGE models with financial frictions, Journal of Macroeconomics, v. 61, WP 1234 (September 2019).

Chiades P., L. Greco, V. Mengotto, L. Moretti and P. Valbonesi, Fiscal consolidation by intergovernmental transfers cuts? The unpleasant effect on expenditure arrears, Economic Modelling, v. 77, pp. 266-275, WP 985 (July 2016).

CIANI E., F. DAVID and G. DE BLASIO, Local responses to labor demand shocks: a re-assessment of the case of Italy, Regional Science and Urban Economics, v. 75, pp. 1-21, WP 1112 (April 2017).

CIANI E. and P. FISHER, Dif-in-dif estimators of multiplicative treatment effects, Journal of Econometric Methods, v. 8. 1, pp. 1-10, WP 985 (November 2014).

CIAPANNA E. and M. TABOGA, Bayesian analysis of coefficient instability in dynamic regressions, Econometrics, MDPI, Open Access Journal, v. 7, 3, pp.1-32, WP 836 (November 2011).

Coletta M., R. De Bonis and S. PIERMATteI, Household debt in OECD countries: the role of supply-side and demand-side factors, Social Indicators Research, v. 143, 3, pp. 1185-1217, WP 989 (November 2014).

Cova P., P. PAgAno and M. PISAni, Domestic and international effects of the Eurosystem Expanded Asset Purchase Programme, IMF Economic Review, v. 67, 2, pp. 315-348, WP 1036 (October 2015).

ERCOLANI V. and J. VAlLE E AZEVEDO, How can the government spending multiplier be small at the zero lower bound?, Macroeconomic Dynamics, v. 23, 8. pp. 3457-2482, WP 1174 (April 2018).

FERrero G., M. Gross and S. NerI, On secular stagnation and low interest rates: demography matters, International Finance, v. 22, 3, pp. 262-278, WP 1137 (September 2017).

FoA G., L. GAmbacorta, L. Guiso and P. E. Mistrulli, The supply side of household finance, Review of Financial Studies, v.32, 10, pp. 3762-3798, WP 1044 (November 2015).

Giordano C., M. MARINUCCI and A. Silvestrini, The macro determinants of firms' and households' investment: evidence from Italy, Economic Modelling, v. 78, pp. 118-133, WP 1167 (March 2018).

Gomellini M., D. Pellegrino and F. GifFoni, Human capital and urban growth in Italy,1981-2001, Review of Urban \& Regional Development Studies, v. 31, 2, pp. 77-101, WP 1127 (July 2017).

MAGRI S., Are lenders using risk-based pricing in the Italian consumer loan market? The effect of the 2008 crisis, Journal of Credit Risk, v. 15, 1, pp. 27-65, WP 1164 (January 2018).

Makinen T., A. MercatANTI and A. Silvestrini, The role of financial factors for european corporate investment, Journal of International Money and Finance, v. 96, pp. 246-258, WP 1148 (October 2017).

Miglietta A., C. Picillo and M. Pietrunti, The impact of margin policies on the Italian repo market, The North American Journal of Economics and Finance, v. 50, WP 1028 (October 2015). 
MONTEFORTE L. and V. RAPONI, Short-term forecasts of economic activity: are fortnightly factors useful?, Journal of Forecasting, v. 38, 3, pp. 207-221, WP 1177 (June 2018).

Neri S. and A. NOTARPIETRO, Collateral constraints, the zero lower bound, and the debt-deflation mechanism, Economics Letters, v. 174, pp. 144-148, WP 1040 (November 2015).

Pereda FERnANDEZ S., Teachers and cheaters. Just an anagram?, Journal of Human Capital, v. 13, 4, pp. 635-669, WP 1047 (January 2016).

RigGi M., Capital destruction, jobless recoveries, and the discipline device role of unemployment, Macroeconomic Dynamics, v. 23, 2, pp. 590-624, WP 871 (July 2012).

2020

COIBION O., Y. GORODNICHENKO and T. ROPELE, Inflation expectations and firms' decisions: new causal evidence, Quarterly Journal of Economics, v. 135, 1, pp. 165-219, WP 1219 (April 2019).

D'IGNAZIO A. and C. MENOn, The causal effect of credit Guarantees for SMEs: evidence from Italy, The Scandinavian Journal of Economics, v. 122, 1, pp. 191-218, WP 900 (February 2013).

RAINONE E. and F. VACIRCA, Estimating the money market microstructure with negative and zero interest rates, Quantitative Finance, v. 20, 2, pp. 207-234, WP 1059 (March 2016).

RIZZICA L., Raising aspirations and higher education. evidence from the UK's widening participation policy, Journal of Labor Economics, v. 38, 1, pp. 183-214, WP 1188 (September 2018).

\section{FORTHCOMING}

ARDUINI T., E. PATACCHINI and E. RAINONE, Treatment effects with heterogeneous externalities, Journal of Business \& Economic Statistics, WP 974 (October 2014).

Bologna P., A. Miglietta and A. Segura, Contagion in the CoCos market? A case study of two stress events, International Journal of Central Banking, WP 1201 (November 2018).

Bottero M., F. MEZZANOTTI and S. LENZU, Sovereign debt exposure and the Bank Lending Channel: impact on credit supply and the real economy, Journal of International Economics, WP 1032 (October 2015).

BRIPI F., D. LOSCHIAVO and D. REVELLI, Services trade and credit frictions: evidence with matched bankfirm data, The World Economy, WP 1110 (April 2017).

BRONZINI R., G. CARAMELLINO and S. MAGRI, Venture capitalists at work: a Diff-in-Diff approach at latestages of the screening process, Journal of Business Venturing, WP 1131 (September 2017).

BRONZINI R., S. MOCETTI and M. MONGARDInI, The economic effects of big events: evidence from the Great Jubilee 2000 in Rome, Journal of Regional Science, WP 1208 (February 2019).

CORSELlO F. and V. NISPI LANDI, Labor market and financial shocks: a time-varying analysis, Journal of Money, Credit and Banking, WP 1179 (June 2018).

Cova P., P. PAgAnO, A. NotarPietro and M. Pisani, Secular stagnation, R\&D, public investment and monetary policy: a global-model perspective, Macroeconomic Dynamics, WP 1156 (December 2017).

GerAli A. and S. NeRI, Natural rates across the Atlantic, Journal of Macroeconomics, WP 1140 (September 2017).

LiBERATI D. and M. LOBERTO, Taxation and housing markets with search frictions, Journal of Housing Economics, WP 1105 (March 2017).

LoschiAvo D., Household debt and income inequality: evidence from italian survey data, Review of Income and Wealth, WP 1095 (January 2017).

Mocetti S., G. RoMA and E. RuBOLINO, Knocking on parents' doors: regulation and intergenerational mobility, Journal of Human Resources, WP 1182 (July 2018).

PANCRAZI R. and M. PietrunTI, Natural expectations and home equity extraction, Journal of Housing Economics, WP 984 (November 2014).

Pereda Fernandez S., Copula-based random effects models for clustered data, Journal of Business \& Economic Statistics, WP 1092 (January 2017).

RAINONE E., The network nature of otc interest rates, Journal of Financial Markets, WP 1022 (July 2015). 